\title{
The main stage of recovery after the end-Permian mass extinction: Taxonomic rediversification and ecologic reorganization of marine level-bottom communities during the Middle Triassic
}

\author{
Evelyn Friesenbichler ${ }^{\text {Corresp., } 1}$, Michael Hautmann ${ }^{1}$, Hugo Bucher ${ }^{1}$ \\ 1 Paläontologisches Institut und Museum, University of Zurich, Zurich, Switzerland \\ Corresponding Author: Evelyn Friesenbichler \\ Email address: evelyn.friesenbichler@pim.uzh.ch
}

The recovery of marine life from the end-Permian mass extinction event provides a testcase for biodiversification models in general, but few studies have addressed this episode in its full length and ecological context. This study analyses the recovery of marine levelbottom communities from the end-Permian mass extinction event over a period of $15 \mathrm{Ma}$, with a main focus on the previously neglected main phase during the Middle Triassic. Our analyses are based on faunas from 37 lithological units representing different environmental settings, ranging from lagoons to inner, mid- and outer ramps. Our dataset comprises 1562 species, which belong to 13 higher taxa and 12 ecological guilds. The diversification pattern of most taxa and guilds shows an initial Early Triassic lag phase that is followed by a hyperbolic diversity increase during the Bithynian (early middle Anisian) and became damped later in the Middle Triassic. The hyperbolic diversity increase is not predicted by models that suggest environmental causes for the initial lag phase. We therefore advocate a model in which diversification is primarily driven by the intensity of biotic interactions. Accordingly, the Early Triassic lag phase represents the time when the reduced species richness in the wake of the end-Permian mass extinction was insufficient for stimulating major diversifications, whereas the Anisian main diversification event started when self-accelerating processes became effective and stopped when nichecrowding prevented further diversification. Biotic interactions that might drive this pattern include interspecific competition but also habitat construction, ecosystem engineering and new options for trophic relationships. The latter factors are discussed in the context of the resurgence of large carbonate platforms, which occurred simultaneously with the diversification of benthic communities. These did not only provide new hardground habitats for a variety of epifaunal taxa, but also new options for grazing gastropods that supposedly fed from microalgae growing on dasycladaceans and other macroalgae. Whereas we do not claim that changing environmental conditions were generally 
unimportant for the recovery of marine level-bottom communities, we note that their actual role can only be assessed when tested against predictions of the biotic model. 
1 The main stage of recovery after the end-Permian

2 mass extinction: Taxonomic rediversification and

3 ecologic reorganization of marine level-bottom

4 communities during the Middle Triassic

5 Evelyn Friesenbichler ${ }^{1}$, Michael Hautmann ${ }^{1}$, Hugo Bucher ${ }^{1}$

$6 \quad{ }^{1}$ Paläontologisches Institut und Museum, University of Zurich, Zurich, Switzerland

8 Corresponding Author:

9 Evelyn Friesenbichler ${ }^{1}$

10 Karl-Schmid-Strasse 4, Zurich, 8006, Switzerland

11 Email address: evelyn.friesenbichler@pim.uzh.ch 


\section{Abstract}

The recovery of marine life from the end-Permian mass extinction event provides a test-case for biodiversification models in general, but few studies have addressed this episode in its full length and ecological context. This study analyses the recovery of marine level-bottom communities from the end-Permian mass extinction event over a period of $15 \mathrm{Ma}$, with a main focus on the previously neglected main phase during the Middle Triassic. Our analyses are based on faunas from 37 lithological units representing different environmental settings, ranging from lagoons to inner, mid- and outer ramps. Our dataset comprises 1562 species, which belong to 13 higher taxa and 12 ecological guilds. The diversification pattern of most taxa and guilds shows an initial Early Triassic lag phase that is followed by a hyperbolic diversity increase during the Bithynian (early middle Anisian) and became damped later in the Middle Triassic. The hyperbolic diversity increase is not predicted by models that suggest environmental causes for the initial lag phase. We therefore advocate a model in which diversification is primarily driven by the intensity of biotic interactions. Accordingly, the Early Triassic lag phase represents the time when the reduced species richness in the wake of the end-Permian mass extinction was insufficient for stimulating major diversifications, whereas the Anisian main diversification event started when self-accelerating processes became effective and stopped when niche-crowding prevented further diversification. Biotic interactions that might drive this pattern include interspecific competition but also habitat construction, ecosystem engineering and new options for trophic relationships. The latter factors are discussed in the context of the resurgence of large carbonate platforms, which occurred simultaneously with the diversification of benthic communities. These did not only provide new hardground habitats for a variety of epifaunal taxa, but also new options for grazing gastropods that supposedly fed from microalgae growing on dasycladaceans and other macroalgae. Whereas we do not claim that changing environmental conditions were generally unimportant for the recovery of marine level-bottom communities, we note that their actual role can only be assessed when tested against predictions of the biotic model.

\section{Introduction}

The end-Permian mass extinction was the most severe extinction event in Earth's history and witnessed the extinction of $81 \%$ (Stanley, 2016) to $96 \%$ (Raup, 1979) of marine species. The aftermath of this event provides a unique test case to study how life rediversified after such a massive loss of species richness and which evolutionary processes were involved. In this study, these processes were analyzed in the ecological context in which they occurred. Previous studies with a similar scope concentrated on the Early Triassic (e.g. Schubert \& Bottjer, 1995; Twitchett \& Wignall, 1996; Hofmann et al., 2013; Hofmann, Hautmann \& Bucher, 2015; Foster et al., 2015; Hautmann et al., 2015; Foster et al. 2017; Foster, Danise \& Twitchett 2017), the time interval of ca. $4 \mathrm{Ma}$ after the end-Permian mass extinction. These studies revealed, among other things, that (1) the recovery of the nekton (e.g. ammonoids and conodonts; Orchard, 2007; Brayard et al., 2009; Brayard \& Bucher, 2015) is remarkably different from that of the benthos (Hofmann, Hautmann \& Bucher, 2013; Hofmann et al., 2013; Hofmann et al., 2014; Friesenbichler et al. 2019), (2) the main recovery phase of the benthos did not start before the Middle Triassic (Nützel, 2005; Hautmann, 2007; Hofmann et al., 2014; Friesenbichler et al., 2021), (3) benthic ecosystem recovery was not completed before the end of the Middle Triassic (Hausmann \& Nützel, 2015) and (4) the resurgence of large carbonate platforms and the recovery of reefs during the Middle Triassic (e.g. Gaetani et al., 1981; Senowbari-Daryan et al., 1993; 
56

57

58

59

60

61

62

63

64

65

66

67

68

69

70

Flügel, 2002) possibly played an important role in the shift of taxonomic composition of benthic communities (Friesenbichler et al., 2019). Despite the fact that the Middle Triassic was obviously a crucial time for the recovery of benthic marine communities, corresponding studies (e.g. Payne, 2005; Payne et al., 2006; Song et al., 2011; Velledits et al., 2011; Foster \& Sebe, 2017; Friesenbichler et al., 2019; Friesenbichler et al., 2021) are still scarce. Relevant questions in the ecological-evolutionary context include: Was the delay in benthic recovery caused by adverse environmental conditions during the Early Triassic (e.g. Hallam, 1991; Wignall \& Twitchett, 1996; Pruss \& Bottjer, 2004; Song et al., 2014), or is it an intrinsic aspect of the diversification dynamics in a largely vacated ecospace (Hautmann et al., 2015)? How did community structures, ecological guilds and ecosystems change during the Middle Triassic, and how did these changes translate into observed diversification patterns? Did the resurgence of large carbonate platforms affect the guild structure, and if yes, which evolutionary processes were involved in the colonization of this new habitat type? What was the relative role of biotic processes such as interspecific competition, habitat alteration, ecosystem engineering and niche construction versus abiotic environmental conditions as controlling factors in diversification and ecosystem evolution? To which diversification model do the empirical patterns conform, and which conclusions does this imply for the diversification of life in general?

\section{Materials \& Methods}

This study is based on data of macroinvertebrate occurrences compiled at the species level from palaeontological studies on Early and Middle Triassic lithological units (Data S1). We preferred this approach over using data from the Palaeobiology Database because it allowed us to control the correctness of the data. The evaluated studies include primarily monographs with well documented faunal lists, but we also considered studies that provide detailed information about macroinvertebrate occurrences including taxonomic assignments. Prime criteria for our selection of studies are the quality of documentation and the coverage of time intervals and environments. Moreover, we sought to include the most diverse lithological unit of each time interval as representatives for the maximum diversity that was possible at a given stage of recovery (see below).

We did not include any species for which we haven't studied the original description and figures. Taxa reported from thin sections or polished slabs were not considered because taxonomic assignments of these taxa were in most cases difficult to verify. The complete dataset includes 37 lithological units comprising 1562 species belonging to gastropods (695 species), bivalves (587 species), brachiopods (147 species), crinoids (33 species), echinoids (31 species), crustaceans (25 species), ophiuroids (12 species), scaphopods (nine species), serpulids (eight species), microconchids (six species), asteroids (four species), bryozoans (four species) and polyplacophores (one species; Data S1). Our approach led to a certain overemphasis of European lithological units (27) in comparison to those from Asia (five) and America (five units from the USA), but the prevailing cosmopolitism of marine faunas of this time (Kristan-Tollmann \& Tollmann, 1982; Schubert \& Bottjer, 1995) justifies the priority of the quality of the documentation over geographic coverage.

\section{Data preparation}


97 The investigated lithological units represent different environments (Data S1). Investigated

98 environments include lagoons (including carbonate platform interiors), inner ramps (above the

99 fair-weather wave base), mid-ramps (between the fair-weather wave base and the storm wave

100 base) and outer ramps (below the storm wave base). The assignment of faunas to a particular

101 environment is based on the information given by the original authors or inferred from the

102 geological and sedimentological context. Studies on lithological units that represent a range of

103 different environments were only considered if the distribution of species within these

104 environments was clear. Therefore, we did not include the Ladinian part of the Cassian

105 Formation (Italy; Urlichs, 2017) in our analyses, although it probably represents the highest

106 benthic diversity of this time interval.

107 From the collected studies, fossil lists were compiled for each lithological unit. If information

108 about one lithological unit was taken from more than one study, attention was paid on possible

109 synonyms.

110 Each species was assigned to an ecological guild, usually based on information given by the

111 original authors. In cases where such information was missing, the ecology was inferred from

112 functional morphology, mode of life of Recent species and information from the literature.

113 Species included in this study represent shallow to moderately deep infaunal suspension-feeders,

114 shallow infaunal deposit-feeders, deep infaunal suspension-feeders, endobyssate

115 suspension-feeders, epibyssate suspension-feeders, free-lying suspension-feeders, cemented

116 epifaunal suspension-feeders, pedunculate suspension-feeders, epifaunal herbivores and/or

117 detritus feeders, epifaunal carnivores, erected epifaunal suspension-feeders and epifaunal

118 detrivore-suspension-feeders (Tab. 1). Gastropods, echinoids and ophiuroids were collectively

119 assigned to epifaunal herbivores and/or detritus-feeders and epifaunal detrivore-

120 suspension-feeders, respectively. We are aware that this might be an over-generalization, but the

121 shell morphology of these taxa does not provide evidence for more specialized feeding in extinct

122 species, and the ecology of Recent species justifies this assignment for most species. Species

123 with uncertain ecology were considered for calculating species richness but were not included in

124 the ecological analyses.

125 Time resolution is provided at the substage level. For lithological units that extend across

126 substages, we assumed constant diversity across substages if the literature suggests that this

127 assumption is justified (e.g. data from the Germanic basin; Schmidt, 1928; Schmidt, 1938).

\section{Data analyses}

129 Conventional diversity studies (e.g. Sepkoski, 1984; Sepkoski, 1997) through deep time have 130 relied on higher taxonomic levels (genera, families, orders) as surrogates for the species level;

131 however this approach may cause a strong bias (Benton, 2001). Unfortunately, compiling reliable

132 global species level curves is virtually impossible because of the higher incompleteness of the

133 fossil record for species than for higher taxa and the necessity of eliminating synonyms. We

134 suggest here a feasible solution for circumventing these problems. We use the maximum species

135 richness among all lithological units in a given time interval as a surrogate for the potentially

136 highest recovery stage that biosphere could reach at this time point after the end-Permian mass

137 extinction (Figs 1 and 2). In other words, for each substage and ecological guild, the lithological

138 unit that contains the highest number of species was used as a reference point. Using this 
139 approach, synonyms are not a major issue because it is irrelevant for the diversity of a given

140 lithological unit whether the same species is described from another lithological unit under a

141 different name.

142 Furthermore, we investigated relative changes in the ecological composition throughout the

143 Early and Middle Triassic (Figs 3 and 4). For this purpose, the guild-species diversity (number of

144 species per guild) for each substage was calculated. To do so, we summarized the number of

145 species that occurred in all lithological units per substage. The sum of species was corrected for

146 double counts, meaning that a species that occurred in several lithological units per substage was

147 only counted once.

\section{Results}

149 Figure 1 shows the huge differences in species richness between Early and Middle Triassic

150 benthic communities that hold across different environments (Fig. 2). The apparent decrease of

151 species richness in the Longobardian (late Ladinian; Figs 1 and 2) is an artefact of the scarcity of

152 data that would disappear e.g. if time-resolved data from the Ladinian part of the Cassian

153 Formation were available (see Methods). Currently, only one lithological unit represents the

154 middle and late Longobardian in Figs 1 and 2. Scarce data may also underlie changes in

155 guild-species diversity seen in the Smithian (early Olenekian) and the Aegean (early Anisian;

156 Fig. 3).

157 Epifaunal herbivores and/or detritus feeders (i.e. gastropods) diversified most quickly in the

158 Middle Triassic. Shallow to moderately deep and deep infaunal, endobyssate, epibyssate,

159 free-lying, cemented and pedunculate suspension-feeders as well as shallow infaunal

160 deposit-feeders started diversifying at the same time (Fig. 5) but their species richness levelled

161 out at lower plateaus.

162 Bivalves, gastropods and brachiopods were the most diverse taxa in Early and Middle Triassic

163 benthic communities (Data S1). Bivalves had a relatively low and constant species richness

164 throughout the Early Triassic and diversified quickly in the Bithynian (early middle Anisian)

165 followed by a plateau (Figs 6A and 7). Except for the Smithian Sinbad Formation, the species

166 richness of gastropods was low in the Early Triassic and started to increase rapidly in the

167 Bithynian and their species richness started to exceed that of bivalves from the Pelsonian (late

168 middle Anisian) onwards (Figs 6B and 7). Brachiopods also diversified in the Bithynian but not

169 to the same extent as bivalves and gastropods did, and their species richness maintained a Middle

170 Triassic plateau (Figs 6C and 7). Especially gastropods but also brachiopods were relatively

171 diverse in lithological units that are associated with carbonate platforms (red lines in Figs 6B and

172 6C). Fig. 6D shows a change in taxonomic composition from bivalve-dominated Early Triassic

173 to increasingly more gastropod-dominated Middle Triassic faunas. Almost all lithological units

174 associated with carbonate platforms are dominated by gastropods, which was already noticed by

175 Friesenbichler et al. (2019).

176 The guild-species diversity of epifaunal herbivores and/or detritus-feeders (i.e. gastropods)

177 changed strongest among all ecological guilds during the studied time interval. During the Early

178 Triassic they were the third most diverse guild but they started to diversify quickly during the

179 Bithynian and became almost instantaneously the dominating guild in Middle Triassic benthic 
180 communities (Fig. 3). The only environment where this trend is not observed are outer ramps, 181 where their species richness remained constant (Figs 2D and 4D). Figures 5A and 5B show that 182 their rapid diversification started in the Bithynian and continued throughout the Anisian.

183 Epibyssate suspension-feeders (chiefly pteriomorphian bivalves) were the most diverse guild in the Induan and the Spathian (late Olenekian). During the Bithynian their absolute richness increased whereas their relative richness decreased (Figs 1, 3, 5C and 5D) and continued to decrease slightly throughout the Middle Triassic. This decrease is also apparent in lagoons, inner and mid-ramps, whereas in outer ramps their relative diversity increased slightly (Fig. 4).

Shallow to moderately deep infaunal suspension-feeders (bivalves and inarticulate brachiopods) were among the most diverse guilds during the Early Triassic but their relative richness decreased gradually after the Aegean (Figs 1 and 3). The same trend occurred in the guild-species diversity in lagoons, mid- and outer ramps; however, in mid-ramps the relative species richness of shallow to moderately deep infaunal suspension-feeders was higher in the late Illyrian (late Anisian) to late Fassanian (early Ladinian) interval than in the late Pelsonian to early Illyrian (Figs 4A, 4C and 4D). In inner ramp settings, the relative amount of shallow to moderately deep infaunal suspension-feeders decreased already during the Spathian. Their main recovery phase started in the Bithynian but the diversification rate seemed to slow down afterwards (Figs 5C and 5D).

At the beginning of the Spathian, the relative richness of endobyssate suspension-feeders (bivalves) started to increase, but after the Aegean, it decreased continuously (Fig. 3). The same trend occurred in lagoons and outer ramps. In inner and mid-ramp settings, the relative amount of endobyssate suspension-feeders was more or less constant after the Spathian (Fig. 4). The species richness of endobyssate suspension-feeders increased constantly during the Early Triassic, followed by a rapid rise in species richness in the Bithynian. However, after this increase their species richness remained constant (Figs 5C and 5D).

The relative amount of pedunculate suspension-feeders (articulate brachiopods) fluctuated. They were relatively diverse during the Griesbachian (early Induan) and after the Bithynian but in between they were rather uncommon. After the early Illyrian they became gradually less diverse (Fig. 1). In Early Triassic mid-ramp settings, they are only recorded from the Griesbachian. Their relative importance was high during the Bithynian, but afterwards they became less common. In outer ramps from the Early Triassic, this guild is only reported from the Griesbachian and Dienerian (late Induan); however, in Middle Triassic outer ramps pedunculate suspensionfeeders were the most diverse guild (Fig. 4D). They experienced a rapid rise in diversification in the Bithynian (Figs 5C and 5D).

Other guilds were rather uncommon during the Early and Middle Triassic or not represented in all time slices (Figs 1 and 3). Deep infaunal suspension-feeders (siphonate bivalves) are first reported from the Spathian (Fig. 3) and showed a weak increase in species richness in the Bithynian (Figs 5E and 5F). The species richness of shallow infaunal deposit-feeders (i.e. nuculid bivalves and scaphopods) and free-lying epifaunal suspension-feeders (bivalves) increased in the Bithynian but stayed constant during the remaining of the Middle Triassic (Figs 5E and 5F). Cemented epifaunal suspension-feeders (e.g. oysters, serpulids, microconchids) and erected epifaunal suspension-feeders (i.e. crinoids) also started to diversify during the Bithynian, 
222 but their later diversification pattern is poorly documented (Figs $5 \mathrm{G}$ and $5 \mathrm{H}$ ). Epifaunal

223 detrivore-suspension feeders (i.e. ophiuroids) and epifaunal carnivores (i.e. asteroids and

224 crustaceans) started to diversify in the Aegean or Bithynian (Figs $5 \mathrm{G}$ and $5 \mathrm{H}$ ).

225

226

227

228

229

230

231

232

233

234

235

236

237

238

239

240

241

242

243

244

245

246

247

248

249

250

251

252

253

254

255

256

257

258

259

260

261

A remarkable aspect of the guild analysis is that the explosive Anisian diversity increase was not associated with the evolution of new benthic guilds, confirming previous observations by Foster \& Twitchett (2014).

\section{Discussion}

\section{Possible biases}

Our data indicate an explosive increase in benthic diversity at the beginning of the Middle Triassic that followed an extended Early Triassic lag phase (Fig. 1). Can this pattern result from a bias in preservation, rock exposure or research history?

A preservation bias in Early Triassic strata has often been proposed as a possible reason for the generally low species richness at that time (e.g. Erwin, 1996; Wignall \& Benton, 1999; Peters \& Foote, 2002; Nützel \& Schulbert, 2005; Hautmann et al., 2011), but well preserved Early Triassic benthic faunas have been reported worldwide, e.g. from the western USA (Batten \& Stokes 1986; Hautmann \& Nützel 2005; Nützel \& Schulbert 2005; Pruss, Payne \& Westacott, 2015; Brayard et al. 2017), South China (Kaim et al., 2010; Hautmann et al., 2011; Hautmann et al., 2015; Foster et al. 2019), Russia (Shigeta et al., 2009) and Pakistan (Wasmer et al. 2012; Kaim et al., 2013); even silicified faunas are known from the Early Triassic of Oman (Twitchett et al., 2004; Wheeley \& Twitchett, 2005; Oji \& Twitchett, 2015) and Svalbard (Foster, Danise \& Twitchett, 2017). However, all these well preserved Early Triassic benthic communities are much less diverse than communities from comparable settings in the Middle Triassic, so their low diversity is probably a primary signal.

Except for taxonomic oversplitting and synonyms (see Methods), the history of research and the size of exposure influence our knowledge on species richness. In our data, the most extreme potential bias in this respect is between the stratigraphically adjacent data points from the Bithynian Tubiphytes-Limestone Member (Romania) and the Jena Formation (Germany), which corresponds to the strongest increase in diversity within the studied time interval. The described fauna from the Tubiphytes-Limestone Member comes from only $1.5 \mathrm{~m}^{3}$ of rock material (Grădinaru \& Gaetani, 2017; Nützel, Kaim \& Grădinaru, 2018; Friesenbichler et al., 2021), and rarefaction analysis indicates that the bivalve fauna is actually insufficiently sampled (Friesenbichler et al., 2021). In contrast, the Germanic Triassic looks back on a long history of research and is represented by a large outcrop area, which should correspond to a significantly higher completeness of sampled biodiversity. However, correcting the data point from the Tubiphytes-Limestone Member towards a higher diversity would solely shift the starting point of the main diversity increase from the middle to the early Bithynian, but not alter the overall shape of the diversity trajectory.

\section{Extrinsic or intrinsic control?}

The observation of an Early Triassic lag phase in the recovery from the end-Permian mass extinction is not new. Schubert \& Bottjer (1995) were among the first to demonstrate this delay 
262 in rediversification based on regional data of post-extinction communities in the western USA.

263 They suggested that the "long pre-radiation period" could be due (1) to the extraordinarily

264 magnitude of the end-Permian mass extinction and/or (2) the persistence of environmental stress.

265 The first explanation implies an evolutionary slow-down of diversification rates that correlates

266 with the extinction magnitude, possibly because there is a positive feedback between species

267

268

269

270

271

272

273

274

275

276

277 richness and rates of speciation, which becomes ineffective if diversity falls below a critical threshold (Solé et al., 2010; Hautmann et al., 2015). The second (environmental) explanation has found disproportionally more attention in the literature, which offers manifold scenarios of poisonous, acidic, oxygen deficient and lethally hot oceans that prevented life from re-diversifying after the great dying at the end of the Permian (e.g. Wignall \& Twitchett, 1996; Payne et al. 2007; Joachimski et al., 2012; Sun et al., 2012; Song et al., 2014). Support for the second explanation has been sought in the demonstration of adverse environmental conditions during the Early Triassic from geochemical or palaeontological proxies (e.g. Payne et al., 2010; Sanei, Grasby \& Beauchamp, 2012; Schobben et al., 2014; Tian et al., 2014; Rothman et al., 2014; Wei et al., 2015), but the idea of pervasive hostile conditions in the Early Triassic has also been criticized for being at variance with a variety of observations. These include: (1) benthic communities from various environmental settings and palaeogeographically distant regions show little indications for unusual environmental stress (Twitchett et al., 2004; Hautmann et al., 2011; Hautmann et al., 2015; Hofmann, Hautmann \& Bucher, 2013; Hofmann et al., 2013; Hofmann et al., 2014); (2) ichnofaunas were diverse and complex soon after the extinction event in different palaeolatitudes (Beatty, Zonneveld \& Henderson, 2008; Hofmann et al., 2011); (3) shell sizes of many Early Triassic gastropods reached large sizes (Brayard et al., 2010; Brayard et al., 2011a; Brayard et al., 2015); (4) diversification of ammonoids was extremely rapid (Brayard et al., 2009); (5) biomass productivity of marine benthos was high in spite of low taxonomic diversity (Brosse et al., 2019) and (6) marine apex predators were present throughout the Early Triassic (Scheyer et al., 2014). This criticism does not deny the existence of environmental stress in the Early Triassic, but it suggests that it was locally and temporarily restricted and had differential impacts on the benthos and nekton.

290

291

Another class of explanations assumes that a breakdown of primary production in the Early

292

293

294

295

296

297

298

299

300 Triassic caused a collapse of the food pyramid. According to these models, the low diversity in the Early Triassic corresponds to a time of reduced primary production (e.g. Grasby et al., 2020) and the recovery of marine life required a successive rebuilding of trophic levels (Chen \& Benton, 2012, p. 379). However, Chen \& Benton (2012) suggested that this model predicts a logistic rediversification curve, which would be at variance with the extended Early Triassic lag phase. Palaeontological data also demonstrate the presence of apex predators in the Early Triassic (Chen \& Benton, 2012; Scheyer et al. 2014), which indicates that trophic levels between the base and the top of the food pyramid were at least partly intact. We add here that low primary production per se does not provide an explanation for low diversity. Theory rather predicts that selection for fitness in resource-poor environments favours specialized, efficient populations and therefore results in high diversity (Valentine, 1971). The high diversity of Recent coral reefs and deep-sea communities (Grassle \& Maciolek, 1992; Veron et al, 2009) are well-known examples

303

304 that conform to this prediction.

305

In contrast to the idea of environmentally driven delay (EDD) models, the biotic interaction (BI) model does not only provide an explanation for the delayed recovery but it also makes a

306 prediction for the diversification pattern that followed the initial lag phase. Mathematically, the 
307 BI model can be written as a differential equation that can be solved numerically. It contains a

308 hyperbolic term that accounts for the positive feedback of species interactions on rates of

309 diversification, which is usually combined with a damping term that limits the increase when the

310 effects of niche pre-emption and ecological crowding become dominant (Solé et al., 2010,

311 equation 10; Hautmann et al., 2015, equation 1). In contrast to the more familiar logistic model

312 (Sepkoski, 1978; Sepkoski, 1984), the shape of the resulting curve is decidedly asymmetrical

313 (compare Figs 8A and 8C). It displays an extended early (left) branch, which represents the

314 prolonged lag phase when feedback processes were ineffective due to low species richness,

315 followed by an explosive increase that stops relatively suddenly when ecospace is filled (Fig.

316 8C). However, the exact shape of the curve depends upon two parameters: (1) the starting

317 diversity that can be expressed as percentage of the carrying capacity or as the percentage of

318 surviving species, and (2) the proportionality factor, which represents the feedback strength.

319 Depending on these two parameters, which are insufficiently known, the shape of the hyperbolic

320 damped diversification curve can appear relatively similar to a logistic shape under certain

321

322

323

324

325

326

327

328

329

330

331

332

333

334

335

336

337

338

339

340

341 conditions, but a qualitative difference between the two models always remains. This difference can be visualized in semilogarithmic plots, where a hyperbolic curve is reflected by an initial increase in the slope of the diversification curve, whereas a logistic curve is represented by a decreasing slope (Figs 8B and 8D).

The majority of the semilogarithmic plots presented in this study (Figs 5 and 7) is conform to the hyperbolic-damped (= BI) model. This applies to the diversification curves of bivalves, gastropods and brachiopods in general, bivalves from mid-ramp settings, as well as shallow infaunal deposit-feeders (i.e., nuculid bivalves and scaphopods) and free-lying epifaunal suspension feeders (some bivalves), with their sudden increase in species richness during the Bithynian that is followed by a plateau, which indicates a hyperbolic-damped increase in species richness. Likewise, the diversification trends of gastropods in mid-ramp settings, epibyssate suspension-feeders (some bivalves), epifaunal herbivores and/or detritus-feeders (i.e., gastropods), erected epifaunal suspension-feeders (i.e., crinoids) and pedunculate suspension-feeders (i.e., articulate brachiopods) show a sudden increase in species richness in the Bithynian, which is as indicative of a hyperbolic trajectory. The data from some other guilds do not provide an unequivocal support for either the hyperbolic or the logistic model. This concerns shallow to moderately deep infaunal, endobyssate and cemented epifaunal suspension-feeders (e.g., some bivalves, serpulids) as well as epifaunal detrivore-suspension-feeders (i.e., ophiuroids). The remaining taxa and guilds (i.e., brachiopods of mid-ramp settings, deep infaunal suspension-feeders and epifaunal carnivores like asteroids and crustaceans) do not match with any model, possibly because of their scarcity in our dataset.

342 A conclusion from these observations is that they suggest a strong effect of biotic interactions on

343

344 rates of diversification. This is the prime difference to the standard logistic model, which makes a neutral assumption with respect to biotic interactions. In the logistic model, the initially exponential increase is solely an effect of an increasing number of species that each have constant diversification rates. This assumption is clearly incompatible with the explosive diversification revealed in our dataset (Fig. 1). Notably, this is not an isolated observation. Miller \& Sepkoski (1988) found "hyperexponential bursts" in the Phanerozoic diversity curve of bivalves during the Ordovician diversification and following the end-Permian and end-Cretaceous mass extinctions, which likely represent times of hyperbolic increase. Markov \& 
351 Korotayev (2007) even proposed that the Phanerozoic biodiversity curve from which Sepkoski

$352(1978,1984)$ derived his model is actually better described by a hyperbolic model.

353 Implicit in these finds is that we cannot expect an early rediversification if the feedback

354 mechanism between richness and rates of diversification was ineffective after an extreme

355 diversity crash, whether or not the environment was favourable. Does this conclusion refute the

356 EDD model? It partly does, because it means that at least a portion of the lag phase is always

357 attributed to BI. It is therefore incorrect to ascribe the full length of the lag phase to EDD.

358 However, it is currently also uncertain whether the full length of the Early Triassic lag phase can

359 be explained solely by the BI model. The length of the lag phase in this model depends upon two

360 parameters, the starting diversity and the proportionality factor, which are not precisely known. It

361 is therefore possible that adverse environmental conditions delayed or interrupted the early

362 recovery whereas the BI model explains a subsequent extension of the lag phase. Clarifying the

363 exact parameters in the BI model equation for different taxa is required for estimating the length

364 of the intrinsic delay and thus the potential for EDD as an additional explanation for the Early

365 Triassic lag phase.

366 From an evolutionary viewpoint, the most relevant aspect is the nature of biotic interactions that

367 cause positive feedbacks between species richness and rates of diversification. Solé et al. (2010)

368 were vague with respect to possible feedback processes, suggesting that increasing numbers of

369 ecological interactions might provide the context for new opportunities to speciate, but they also

370 noted that this process might operate too slowly to explain explosive diversification.

371 Alternatively, they proposed that the growing number of potential interactions might drive the

372 increase in the number of species. Hautmann et al. (2015) reconsidered the problem and

373 identified interspecific competition as a potential main driver of hyperbolic-damped

374 diversification curves. Accordingly, promotion of niche differentiation is the dominant outcome

375 of interspecific competition until a critical level of ecological saturation has been reached, at

376 which further division of niche space requires increasingly elaborated adaptations that are more

377 and more unlikely to evolve. Above such a saturation limit, outcompeting of existing species

378 becomes the prevalent effect of competition, which damps further diversification. A strength of

379 this model is that it correctly predicts different diversification trajectories for taxa with

380 supposedly different intensities of interspecific competition, for which slowly recovering

381 bivalves contrasted by explosively rediversifying ammonoids have been cited as an example

382 (Hautmann et al., 2015). The fact that the phase of the hyperbolic diversity increase was not

383 associated with the origin of new guilds further supports the competition-driven scenario,

384 because competition is most intense between species with similar lifestyles. However, Hautmann

385 et al. (2015) also noted that many other aspects in addition to competition affect actual patterns

386 of diversification. In the following, we discuss some possible additional factors that were linked

387 to the resurgence of carbonate platforms in the Middle Triassic.

388 Habitat construction and biotic interactions on resurging large carbonate platforms

389 The recovery of large carbonate platforms after the end-Permian mass extinction started in the

390 Anisian (early Middle Triassic; Gaetani et al., 1981; Senowbari-Daryan et al. 1993; Berra,

391 Rettori \& Bassi, 2005), and coincided with the main diversification of most benthic marine

392 invertebrate taxa (Figs 5 and 7). One of the oldest Triassic carbonate platforms is represented by

393 the Tubiphytes-Limestone Member of the Caerace Formation in Romania. This Bithynian

Peer) reviewing PDF | (2020:10:54335:1:0:NEW 7 May 2021) 
394 biostrome is dominated by the micro-encruster Tubiphytes and large volumes of synsedimentary

395 cements (Popa, Panaiotu \& Grădinaru, 2014) and provided the basis for a rich hardground

396 community that is much more diverse than contemporaneaus level-bottom faunas (Grădinaru \&

397 Gaetani, 2017; Forel \& Grădinaru, 2018; Nützel, Kaim \& Grădinaru, 2018; Friesenbichler et

398 al., 2021). Its high amount of newly described species is potentially related to the new habitat

399 type. This applies to the dominant taxa, i.e., epibyssate bivalves, gastropods and brachiopods

400 (Data S1) that were well adapted to the hardgrounds provided by the Tubiphytes-microbial

401

402

403

404

405

406

407

408

409

410 Reefs existed throughout the Triassic, but their composition changed stepwise (see Martindale, buildup (Friesenbichler et al., 2021). Further Middle Triassic Tubiphytes-dominated buildups are known from the Iranian carbonate mounds of Nakhlak (late Bithynian; Berra et al., 2012), the Italian Camorelli platform (Bithynian-Pelsonian; Gaetani \& Gorza, 1989) and Dont Formation (Pelsonian-Illyrian; Blendinger, 1983; Fois \& Gaetani, 1984), the Hungarian Aggtelek reef (Pelsonian-Ladinian; Velledits et al., 2011; Velledits, Hips \& Péró, 2012) and Chinese reefs (Anisian; Enos, Wei \& Yan, 1997; Lehrmann 1999; Enos et al., 2006; Payne et al., 2006a; Payne et al. 2006b; Lehrmann et al. 2007). The latter flourished on the Great Bank of Guizhou, an isolated carbonate platform in the Nanpanjiang Basin, and represent the oldest Triassic platform margin reefs (Lehrmann, Wei \& Enos, 1998; Payne et al. 2006a; Payne et al. 2006b). 411 Foster \& Velledits, 2019). The oldest Triassic reefs are represented by microbial-metazoan reefs 412 that formed immediately after the end-Permian mass extinction (e.g. Lehrmann et al., 2001; 413 Flügel, 2002; Pruss et al., 2006; Wu et al., 2007; Kiessling \& Simpson, 2011; Kershaw et al., 414 2011; Ezaki, Liu \& Adachi, 2012; Yang et al., 2015, Friesenbichler et al. 2018). The first 415 metazoan reefs are reported from the Olenekian (late Early Triassic) and represent small sponge 416 biostromes and bivalve build-ups (Pruss, Payne \& Bottjer, 2007; Brayard et al., 2011b; 417 Marenco et al., 2012). Reefs developed quickly in the middle Anisian (Flügel, 2002) and in 418 addition to Tubiphytes other organisms such as sphinctozoans (segmented calcareous sponges), dasycladacean algae, corals, and in some cases also bivalves became important reef-builders (Flügel, 2002; Fürsich \& Hautmann, 2005; Senowbari-Daryan \& Link, 2011). These organisms acted as ecological engineers and created new niches that provided opportunities for additional species. Well-documented examples are bivalve-crinoid reef mounds from the Trochitenkalk Formation (middle Illyrian, Germany; e.g. Hagdorn, 1978; Sellwood \& Fürsich, 1981; Hagdorn \& Mundlos, 1982; Flügel, 2002; Hagdorn, 2004; Hagdorn \& Nitsch, 2009), where shell beds were incrusted by cementing bivalves that provided hardgrounds for the colonization by crinoids. These $\mathrm{dm}$-scaled bioherms provided new habitats for brachiopods, serpulids, other bivalves and boring worm-like organisms.

428

429

430

431

432

433

434

435

436

437

438
The sudden increase in species richness of gastropods is another feature of the Middle Triassic main stage of marine recovery (Figs. 1, 2, 3, 4, 5A, 5B, 6B and 7) that was at least partly linked to the resurgence of large carbonate platforms. As shown by Friesenbichler et al (2019, fig. 14), the ratio of gastropod versus bivalve species is much higher in carbonate platforms than in other settings. However, the data of Friesenbichler et al. (2019b) might even underestimate the true signal. Roden et al. (2020) compared the diversity of the Cassian Formation, an exceptional Triassic lagerstätte, with the diversity of the Wetterstein Formation, which is environmentally comparable and approximately of the same age. They found that all mollusks were underrepresented in the Wetterstein Formation by factor 7 in comparison to the Cassian Formation, but gastropods by the astonishing factor 87 . The cause for the affinity of gastropods to carbonate platform facies remains speculative, not at least because the life habit and feeding 
439

440

441

442

443

444

445

446

447

448

449

450

451

452

453

454

455

456

457

458

459

460

461

462

463

464

465

466

467

468

469

470

471

472

473

474

475

476

477

478

479

480

481

482

mode of gastropods cannot be deduced from the shell morphology. In spite of this limitation, we put forward the hypothesis that the quick diversification of gastropods in carbonate platform environments might have been related to the proliferation of dasycladacean algae, which were dominant carbonate producers in many settings where gastropods became diverse.

Palaeoecological studies have previously suggested that at least some Triassic gastropods lived in association with macroalgae (Fürsich \& Wendt, 1977; Sellwood \& Fürsich, 1981; Stiller, 2001; Hagdorn, 2004; Nützel \& Schulbert, 2005; Diedrich, 2010; Urlichs, 2014). This conclusion was derived from the ecology of Recent macroalgae (e.g. Davies, 1970; Taylor, 1971; Thomassin, 1971; Brasier, 1975; Poulicek, 1985; Sánchez-Moyano et al., 2000; Chemello \& Milazzo, 2002; Antoniadou \& Chintiroglou, 2005; Pitacco et al., 2014; Duarte et al., 2015; Chiarore et al., 2017), on which gastropods grazed (e.g. Underwood, 1980; Johnson \& Mann, 1986; Williams, 1993) and thereby enhance the photosynthetic capacity of the host algae (Amsler et al., 2015). The Triassic fossil record of non-calcifying algae is virtually non-existent, but the diversification and abundance of dasycladaceans at the beginning of the Middle Triassic is well established. In our dataset, only 5 out of 37 lithological units contain information about the number of Dasycladacea species associated with the investigated faunas (e.g., Salomon, 1895; Ogilvie Gordon, 1927; Schmidt, 1928; Schmidt, 1938; Granier \& Grgasović, 2000; Russo et al., 2000; Emmerich et al., 2005; Piros \& Preto, 2008). Given the small number of datapoints, the positive correlation between the richness of dasycladaceans and gastropods is statistically not robust $\left(\mathrm{r}^{2}=0.25 ; \mathrm{p}=0.32\right)$, but it is strengthened by an indirect line of evidence. Middle Triassic gastropod diversity decreased towards deeper water settings (Figs 2 and 4), along with declining light. Because light limits the distribution of algae, it is certain that this trend was matched by decreasing macroalgae abundance.

\section{Conclusions}

Data on species richness from 37 Early and Middle Triassic lithological units containing level-bottom communities indicate that most of the analyzed taxa and guilds followed a hyperbolic-damped diversity trajectory, with an extended Early Triassic lag phase followed by an explosive increase in diversity at the beginning of the Middle Triassic that levelled out in the Ladinian. The Early Triassic delay in rediversification of benthic organisms has conventionally been attributed to ongoing environmental stress at that time, but the explosive (hyperbolic rather than exponential) diversity increase at the beginning of the Middle Triassic cannot be explained by relaxation of environmental stress. Our data therefore support a model in which the intensity of biotic interactions determines the rate of diversification. Accordingly, the Early Triassic delay in rediversification represents the time in which the intensity of biotic interactions was too low for driving a major diversification because of the dramatic loss of species during the end-Permian mass extinction. Conversely, the hyperbolic Middle Triassic diversity increase occurred when self-accelerating processes became effective, and it stopped when niche-crowding prevented further diversification. This pattern is in agreement with a competition-driven diversification model that predicts a reversal in the effects of interspecific competition on diversification rates from accelerating to damping. Apart from interspecific competition, other ecological feedbacks might have stimulated the hyperbolic increase in diversity during the Anisian. Carbonate platforms, which reappeared simultaneously with the main stage of benthic rediversification, provided the ecological context for rich hardground communities. The coincidence of the resurgence of carbonate platforms and the evolution of reef-builders with the

Peer) reviewing PDF | (2020:10:54335:1:0:NEW 7 May 2021) 
483

484

485

486

487

488

489

490

491

492

493

494

495

496

497

498

499

500

501

502

503

504

505

506

507

508

509

510

511

512

513

514

515

516

517

518

main diversification of benthic faunas suggests a positive loop effect, which is confirmed by several case studies. When reefs diversified, other reef-builders became abundant and acted as ecological engineers and niche constructers, providing new habitats for additional species. The quick diversification of gastropods in Middle Triassic carbonate platforms might be related to the proliferation of macroalgae, which provided much improved opportunities for grazing. A strength of the biotic interaction model is that it correctly predicts both an extended lag phase and a hyperbolic increase in diversity thereafter, whereas environmental scenarios fail to predict the second aspect.

\section{Acknowledgments}

EF is deeply grateful to Alexander Pohle for interesting and helpful discussions and his loving support. Christian Klug is thanked for helpful discussions. The paper benefitted from constructive reviews by William Foster, Alexander Nützel and an anonymous reviewer. Helpful inputs by editor Diogo Provente are gratefully acknowledged. This work was supported by the SNF grant 200020-162402/1 (to MH).

\section{References}

ABERHAN, M. 1994. Guild-Structure and Evolution of Mesozoic Benthic Shelf Communities. Palaios, 9, 516-545.

AMSLER, M. O., HUANG, Y. M., ENGL, W., MCCLINTOCK, J. B. and AMSLER, C. D. 2015. Abundance and diversity of gastropods associated with dominant subtidal macroalgae from the western Antarctic Peninsula. Polar Biology, 38, 1171-1181.

ANTONIADOU, C. and CHINTIROGLOU, C. 2005. Biodiversity of zoobenthic hard-substrate sublittoral communities in the Eastern Meditarranean (North Aegean Sea). Estuarine, Coastal and Shelf Science, 62, 637-653.

BATTEN, R. L. and STOKES, W. M. L. 1986. Early Triassic gastropods from the Sinbad member of the Moenkopi Formation, San Rafael Swell, Utah. AmMusNov, 2864, 1-33.

BEATTY, T. W., ZONNEVELD, J. P., HENDERSON, C. M. 2008. Anomalously diverse Early Triassic ichnofossil assemblages in Northwest Pangea: a case for a shallow-marine habitable zone. Geology 36, 771-774.

BENTON, M. J. 2001. Biodiversity on land and in the sea. Geological Journal, 36, 211-230.

BERRA, F., BALINI, M., LEVERA, M., NICORA, A. and SALAMATI, R. 2012. Anatomy of carbonate mounds from the Middle Anisian of Nakhlak (Central Iran): architecture and age of a subtidal microbial-bioclastic carbonate factory. Facies, 58, 685-705.

BERRA, F., RETTORI, R. and BASSI, D. 2005. Recovery of carbonate platform production in the Lombardy Basin during the Anisian: paleoecological significance and constrain on paleogeographic evolution. Facies, 50, 615-627.

BLENDINGER, W. 1983. Anisian sedimentation and tectonics of the M. Pore - M. Cernera area 
(Dolomites). Rivista Italiana di Paleontologia e Stratigrafia, 89, 175-208.

520

521

522

523

524

525

526

527

528

529

530

531

532

533

534

535

536

537

538

539

540

541

542

543

544

545

546

547

548

549

550

551

552

553

554

555

BRASIER, M. D. 1975. Ecology of Recent sediment-dwelling and phytal foraminifera from the lagoons of Barbuda, West Indies. Journal of Foraminiferal Research, 5, 42-62.

BRAYARD, A. and BUCHER, H. 2015. Permian-Triassic Extinctions and Rediversifications. In KLUG, C., KORN, D., DE BEATS, K., KRUTA, I., MAPES, R. H. and LANDMAN, N. H. (eds.) Ammonoid Paleobiology: From Anatomy to Ecology, Springer-Verlag, 465-473 pp.

BRAYARD, A., ESCARGUEL, G., BUCHER, H., MONNET, C., BRÜHWILER, T., GOUDEMAND, N., GALFETTI, T. and GUEX, J. 2009. Good genes and good luck: Ammonoid diversity and the end-permian mass extinction. Science, 325, 1118-1121.

BRAYARD, A., KRUMENACKER, L. J., BOTTING, J. P., JENKS, J. F., BYLUND, K. G., FARA, E., VENNIN, E., OLIVIER, N., GOUDEMAND, N., SAUCÈDE, T., CHARBONNIER, S., ROMANO, C., DOGUZHAEVA, L., THUY, B., HAUTMANN, M., STEPHEN, D. A., THOMAZO, C. and ESCARGUEL, G. 2017. Unexpected Early Triassic marine ecosystem and the rise of the Modern evolutionary fauna. Science Advances, 3, e1602159.

BRAYARD, A., MEIER, M., Escarguel, G., FARA, E., NÜTZEL, A., OLIVIER, N., BYLUND, K. G., JENKS, J. F., STEPHEN, D. A., HAUTMANN, M., VENNIN, E. and BUCHER, H. 2015. Early Triassic Gulliver gastropods: Spatiotemporal distribution and significance for biotic recovery after the end-Permian mass extinction. Earth-Science Reviews, 146, 31-64.

BRAYARD, A., NÜTZEL, A., STEPHEN, D. A., BYLUND, K. G., JENKS, J. and BUCHER, H. 2010. Gastropod evidence against the Early Triassic Lilliput effect. Geology, 38, 147150 .

BRAYARD, A., NÜTZEL, A., KAIM, A., ESCARGUEL, G., HAUTMANN, M., STEPHEN, D. A., BYLUND, K. G., JENKS, J. and BUCHER, H. 2011a. Gastropod evidence against the Early Triassic Lilliput effect: reply. Geology, 39, e233.

BRAYARD, A., VENNIN, E., OLIVIER, N., BYLUND, K. G., JENKS, J., STEPHEN, D. A., BUCHER, H., HOFMANN, R., GOUDEMAND, N. and ESCARGUEL, G. $2011 \mathrm{~b}$. Transient metazoan reefs in the aftermath of the end-Permian mass extinction. Nature Geoscience, 4, 693-697.

BROSSE, M., BUCHER H., BAUD, A., FRISK, A., GOUDEMAND, N., HAGDORN, H., NÜTZEL, A., WARE, D. and HAUTMANN, M. 2019. New data from Oman indicate benthic high biomass productivity coupled with low taxonomic diversity in the aftermath of the Permian-Triassic Boundary mass extinction. Lethaia, 52, 165-187.

CHEMELLO, R. and MILAZZO, M. 2002. Effect of algal architecture on associated fauna: some evidance from phytal molluscs. Marine Biology, 140, 981-990.

CHEN, Z.-Q. and BENTON, M. J. 2012. The timing and pattern of biotic recovery following the 
end-Permian mass extinction. Nature Geoscience, 5, 375-383.

557

558

559

560

561

562

563

564

565

566

567

568

569

570

571

572

573

574

575

576

577

578

579

580

581

582

583

584

585

586

587

588

589

590

CHIARORE, A., FIORETTI, S., MECCARIELLA, A., SACCONE, G. and PATTI, P. 2017. Molluscs community associated with the brown algae of the genus Cystoseira in the Gulf of Naples (South Tyrrhenian Sea). BioRxiv, nicht peer.

COHEN, K. M., FINNEY, S. C., GIBBARD, P. L. and FAN, J.-X. 2013. The ICS international chronostratigraphic chart. Episodes, 36, 199-204.

DAVIES, G. R. 1970. Carbonate bank sedimentation, eastern Shark Bay, Western Australia. Memoirs of the American Association of Petroleum Geologists, 13, 85-168.

DIEDRICH, C. G. 2010. Palaeoecology of Placodus gigas (Reptilia) and other placodontids Middle Triassic macroalgae feeders in the Germanic Basin of central Europe - and evidence for convergent evolution with Sirenia. Palaeogeography, Palaeoclimatology, Palaeoecology, 286, 287-306.

DUARTE, R. C. S., MOTA, E. L. S., ALMEIDA, I. C. S., PESSANHA, A. L. M., CHRISTOFFERSEN, M. L. and DIAS, T. L. P. 2015. Gastropods associated to three reef macroalgae with different architectures. Strombus, 22, 5-18.

EMMERICH, A., ZAMPARELLI, V., BECHSTÄDT, T. and ZÜHLKE, R. 2005. The reefal margin and slope of a Middle Triassic carbonate platform: the Latemar (Dolomites, Italy). Facies, 50, 573-614.

ENOS, P., LEHRMANN, D. J., WEI, J., YU, Y., JIAFEI, X., CHAICHIN, D. H., MINZONI, M., BERRI, A. C. and MONTGOMERY, P. 2006. Triassic Evolution of the Yangtze Platform in Guizhou Province, People's Republic of China. Geological Society of America Special Paper, 417, 1-105.

ENOS, P., WEI, J. I. and YAN, Y. . 1997. Facies distribution and retreat of Middle Triassic platform margin, Guizhou Province, South China. Sedimentology, 44, 563-584.

ERWIN, D. H. 1996. Understanding biotic recoveries: extinction, survival and preservation during the end-Permian mass extinction. In JABLONSKI, D., ERWIN, D. H. and LIPPS, J. H. (eds.) Evolutionary Paleobiology, Chicago Press, Chicago, 398-418 pp.

EZAKI, Y., LIU, J. B. and ADACHI, N. 2012. Lower Triassic stromatolites in Luodian County, Guizhou Province, South China: evidence for the protracted devastation of the marine environments. Geobiology, 10, 48-59.

FLÜGEL, E. 2002. Triassic reef patterns. Special Publication - Society for Sedimentary Geology, 72, 391-463.

FOIS, E. and GAETANI, M. 1984. The recovery of reef-building communities and the role of cnidarians in carbonate sequences of the Middle Triassic (Anisian) in the Italian Dolomites. Paleontographica Americana, 54, 191-200.

Peer) reviewing PDF | (2020:10:54335:1:0:NEW 7 May 2021) 
591

592

593

594

595

596

597

598

599

600

601

602

603

604

605

606

607

608

609

610

611

612

613

614

615

616

617

618

619

620

621

622

623

624

625

626

627

FOREL, M.-B. and GRĂDINARU, E. 2018. First report of ostracods (Crustacea) associated with Bithynian (Anisian, Middle Triassic) Tubiphytes-microbial reef in the North Dobrogean Orogen (Romania). Papers in Palaeontology, 4, 211-244.

FOSTER, W. J. and SEBE, K. 2017. Recovery and diversification of marine communities following the late Permian mass extinction event in the western Palaeotethys. Global and Planetary Change, 155, 165-177.

FOSTER, W. J., DANISE, S. and TWITCHETT, R. J. 2017. A silicified Early Triassic marine assemblage from Svalbard. Journal of Systematic Palaeontology, 15, 851-877.

FOSTER, W. J., DANISE, S., PRICE, G. D. and TWITCHETT, R. J. 2017. Subsequent biotic crises delayed marine recovery following the late Permian mass extinction event in northern Italy. PLOS ONE, 12, e0172321.

FOSTER, W. J., DANISE, S., SEDLACEK, A., PRICE, G. D., HIPS, K. and TWITCHETT, R. J. 2015. Environmental controls on the post-Permian recovery of benthic, tropical marine ecosystems in western Palaeotethys (Aggtelek Karst, Hungary). Palaeogeography, Palaeoclimatology, Palaeoecology, 440, 374-394.

FOSTER, W. J., LEHRMANN, D. J., HIRTZ, J. A., WHITE, M., YU, M., LI, J. and MARTINDALE, R. C: 2019. Early Triassic benthich invertebrates from the Great Bank of Guizhou, South China: Systematic palaeontology and palaeobiology. Papers in Palaeontology, 5, 613-656.

FOSTER, W. J. and TWITCHETT, R. J. 2014. Functional diversity of marine ecosystems after the Late Permian mass extinction event. Nature Geoscience, 7, 233-238.

FRIESENBICHLER, E., HAUTMANN, M., GRĂDINARU, E. and BUCHER, H. 2021. A highly diverse bivalve fauna from a Bithynian (Anisian, Middle Triassic) Tubiphytesmicrobial buildup in North Dobrogea (Romania). Papers in Palaeontology, 7, 447-495.

FRIESENBICHLER, E., HAUTMANN, M., NÜTZEL, A., URLICHS, M. and BUCHER, H. 2019. Palaeoecology of Late Ladinian (Middle Triassic) benthic faunas from the Schlern/Sciliar and Seiser Alm/Alpe di Siusi area (South Tyrol, Italy). Paläontologische Zeitschrift, 93, 1-29.

FRIESENBICHLER, E., RICHOZ, S., BAUD, A., KRYSTYN, L., SAHAKYAN, L., VARDANYAN, S., PECKMANN, J., REITNER, J. and HEINDEL, K. 2018. Spongemicrobial build-ups from the lowermost Triassic Chanakhchi section in southern Armenia: Microfacies and stable carbon isotopes. Palaeogeography, Palaeoclimatology, Palaeoecology, 490, 653-672.

FÜRSICH, F. T. and HAUTMANN, M. 2005. Bivalve reefs from the Upper Triassic of Iran. Annali dell'Universitá degli Studi di Ferrara, Museologia Scientifica e Naturalistica, Special volume in honour of Carmela Loriga, 13-23.

FÜRSICH, F. T. and WENDT, J. 1977. Biostratinomy and palaeoecology of the cassian 
628

629

630

631

632

633

634

635

636

637

638

639

640

641

642

643

644

645

646

647

648

649

650

651

652

653

654

655

656

657

658

659

660

661

662

663

formation (Triassic) of the Southern Alps. Palaeogeography, Palaeoclimatology, Palaeoecology, 22, 257-323.

GAETANI, M. and GORZA, M. 1989. The Anisian (Middle Triassic) carbonate bank of Camorelli (Lombardy, southern Alps). Facies, 21, 41-56.

GAETANI, M., FOIS, E., JADOUL, F. and NICORA, A. 1981. Nature and evolution of Middle Triassic carbonate buildups in the Dolomites (Italy). Marine Geology, 44, 25-57.

GÖTZ, A., SZULC, J. and FEIST-BURKHARDT, S. 2005. Distribution of sedimentary organic matter in Anisian carbonate series of S Poland: evidence of third-order sea-level fluctuations. International Journal of Earth Sciences (Geologische Rundschau), 94, 267274.

GRĂDINARU, E. and GAETANI, M. 2017. Spathian to Bithynian (Early to Middle Triassic) brachiopods from North Dobrogea (Romania) Spathian to Bithynian (Early to Middle Triassic) brachiopods from North Dobrogea (Romania). 11th Romanian Symposium on Palaeontology, 49.

GRANIER, B. R. C. and GRGASOCIĆ, T. 2000. Les Algues Dasycladales du Permien et du Trias - Nouvelle tentative d'inventaire bibliographique, géographique et stratigraphique. Geologia Croatica, 53, 1-197.

GRASBY, S. E., KNIES, J., BEAUCHAMP, B., BOND, D. P., WIGNALL, P. and SUN, Y. 2020. Global warming leads to Early Triassic nutrient stress across northern Pangea. GSA Bulletin, 132, 943-954.

GRASSLE, J F. and MACIOLEK, N. J. 1992. Deep-sea species richness: regional and local diversity estimates from quatitative bottom samples. The American Naturalist, 139, 313341.

HAGDORN, H. 1978. Muschel/Krinoiden-Bioherme im Oberen Muschelkalk (mo1, Anis) von Crailsheim und Schwäbisch Hall (Südwestdeutschland). Neues Jahrbuch für Geologie und Paläontologie Abhandlungen, 156, 31-86.

HAGDORN, H. 2004. Muschelkalkmuseum Ingelfingen. Edition Lattner, Lattner Photographic Art GmbH, Heilbronn.

HAGDORN, H. and MUNDLOS, R. 1982. Autochthonschille im Oberen Muschelkalk (Mitteltrias) Südwestdeutschlands. Neues Jahrbuch für Geologie und Paläontologie, Abhandlungen, 162, 332-351.

HAGDORN, H. and NITSCH, E. 2009. The Germanic Triassic in its Southwest German type area. 6th International Triassic Field Workshop (Pan-European Correlation of the Triassic) Triassic of Southwest Germany 175th Anniversary of the Foundation of the Triassic System by Friedrich von Alberti September 7-11, 2009, Tübingen and Ingelfingen, 72.

HALLAM, A. 1991. Why was there a delayed radiation after the end-Palaeozoic extinctions?

Peer) reviewing PDF | (2020:10:54335:1:0:NEW 7 May 2021) 
665 HAUSMANN, I. M. and NÜTZEL, A. 2015. Diversity and palaeoecology of a highly diverse Late Triassic marine biota from the Cassian Formation of north Italy. Lethaia, 48, 235-255.

667

668

669

670

671

672

673

674

675

676

677

678

679

680

681

682

683

684

685

686

687

688

689

690

691

692

693

694

695

696

697

698

699

700

HAUTMANN, M. 2007. Steuerungsfaktoren globaler Biodiversifizierungsmuster am Beispiel frühmesozoischer Muscheln. Beringeria, 37, 61-74.

HAUTMANN, M. and NÜTZEL, A. 2005. First record of a heterodont bivalve (Mollusca) from the Early Triassic: palaeoecological significnce and implications for the 'Lazarus Problem'. Palaeontology, 48, 1131-1138.

HAUTMANN, M., BAGHERPOUR, B., BROSSE, M., FRISK, Å. M., HOFMANN, R., BAUD, A., NÜTZEL, A., GOUDEMAND, N. and BUCHER, H. 2015. Competition in slow motion: The unusual case of benthic marine communities in the wake of the end-Permian mass extinction. Palaeontology, 58, 871-901.

HAUTMANN, M., BUCHER, H., BRÜHWILER, T., GOUDEMAND, N., KAIM, A. and NÜTZEL, A. 2011. An unusually diverse mollusc fauna from the earliest Triassic of South China and its implications for benthic recovery after the end-Permian biotic crisis. Geobios, 44, 71-85.

HOFMANN, R., GOUDEMAND, N., WASMER, M., BUCHER, H. and HAUTMANN, M. 2011. New trace fossil evidence for an early recovery signal in the aftermath of the endPermian mass extinction. Palaeogeography, Palaeoclimatology, Palaeoecology, 310, 216226.

HOFMANN, R., HAUTMANN, M. and BUCHER, H. 2015. Recovery dynamics of benthic marine communities from the Lower Triassic Werfen Formation, northern Italy. Lethaia, 48, 474-496.

HOFMANN, R., HAUTMANN, M., and BUCHER, H. 2013. A new paleoecological look at the Dinwoody Formation (Lower Triassic, Western USA): Intrinsic versus extrinsic controls on ecosystem recovery after the end-Permian mass extinction. Journal of Paleontology, 87, 854-880.

HOFMANN, R., HAUTMANN, M., BRAYARD, A., NÜTZEL, A., BYLUND, K. G., JENKS, J. F., VENNIN, E., OLIVIER, N. and BUCHER, H. 2014. Recovery of benthic marine communities from the end-Permian mass extinction at the low latitudes of eastern Panthalassa. Palaeontology, 57, 547-589.

HOFMANN, R., HAUTMANN, M., WASMER, M. and BUCHER, H. 2013. Palaeoecology of the Spathian Virgin Formation (Utah, USA) and its implications for the Early Triassic recovery. Acta Palaeontologica Polonica, 58, 149-173.

JATTIOT, R., BRAYARD, A., BUCHER, H., VENNIN, E., CARAVACA, G., JENKS, J. F. and BYLUND, K. G. 2018. Palaeobiogeographical distribution of Smithian (Early Triassic) ammonoid faunas within the Western USA Basin and its controlling parameters. 
701

702

703

704

705

706

707

708

709

710

711

712

713

714

715

716

717

718

719

720

721

722

723

724

725

726

727

728

729

730

731

732

733

734

735

736

Palaeontology, 61, 881-904.

JOACHIMSKI, M. M., LAI, X., SHEN, S., JIANG, H., LUO, G., CHEN, B., CHEN, J. and SUN, Y. 2012. Climate warming in the latest Permian and the Permian-Triassic mass extinction. Geology, 40, 195-198.

JOHNSON, C. R. and MANN, K. H. 1986. The importance of plant defence abilities to the structure of subtidal seaweed communities: the kelp Laminaria longicruris de la Pylaie survives grazing by the snail Lacuna vincta (Montagu) at high population densities. Journal of Experimental Marine Biology and Ecology, 97, 231-267.

KAIM, A., NÜTZEL, A., BUCHER, H., BRÜHWILER, T. and GOUDEMAND, N. 2010. Early Triassic (Late Griesbachian) gastropods from South China (Shanggan, Guangxi). Swiss Journal of Geosciences, 103, 121-128.

KAIM, A., NÜTZEL, A., HAUTMANN, M. and BUCHER, H. 2013. Early Triassic gastropods from Salt Range, Pakistan. Bulletin of Geosciences, 88, 505-516.

KERSHAW, S., CRASQUIN, S., FOREL, M.-B., RANDON, C., COLLIN, P.-Y., KOSUN, E., RICHOZ, S. and BAUD, A. 2011. Earliest Triassic microbialites in Çürük Dag, southern Turkey: composition, sequences and controls on formation. Sedimentology, 58, 739-755.

KIESSLING, W. and SIMPSON, C., 2011. On the potential for ocean acidification to be a general cause of ancient reef crises. Global Change Biology, 17, 56-67.

KRISTAN-TOLLMANN, E. and TOLLMANN, A. 1982. Die Entwicklung der Tethystrias und Herkunft ihrer Fauna (The development of the Triassic within the Tethys realm and the origin of its fauna). Geologische Rundschau, 71, 987-1019.

LEHRMANN, D. J. 1999. Early Triassic calcimicrobial mounds and biostromes of the Nanpanjiang basin, China. Geology, 27, 359-362.

LEHRMANN, D. J., PAYNE, J. L., PEI, D., ENOS, P., DRUKE, D., STEFFEN, K., ZHANG, J., WEI, J., ORCHARD, M. and ELLWOOD, B. 2007. Record of the end-Permian extinction and Triasic biotic recovery in the Chongzuo-Pingguo platform, southern Nanpanjiang basin, Guangxi, south China. Palaeogeography, Palaeoclimatology, Palaeoecology, 252, 200-217.

LEHRMANN, D. J., WAN, Y., WEI, J., YU, Y. and XIAO, J. 2001. Lower Triassic peritidal cyclic limestone: an example of anachronistic carbonate facies from the Great Bank of Guizhou, Nanpanjiang Basin, Guizhou provice, South China. Palaeogeography, Palaeoclimatology, Palaeoecology, 173, 103-123.

LEHRMANN, D. J., WEI, J. and ENOS, P. 1998. Controls on facies architecture of a large Triassic carbonate platform; the Great Bank of Guizhou, Nanpanjiang Basin, South China. Journal of Sedimentology, 68, 311-326.

LI, M., HUANG, C., HINNOV, L., CHEN, W., OGG, J. and TIAN, W. 2018. Astrochronology

Peer) reviewing PDF | (2020:10:54335:1:0:NEW 7 May 2021) 
737

740

741

742

743

744

745

746

747

748

749

750

751

752

753

754

755

756

757

758

759

760

761

762

763

764

765

766

767

768

769

770

of the Anisian stage (Middle Triassic) at the Guandao reference section, South China. Earth and Planetary Science Letters, 482, 591-606.

MARENCO, P. J., GRIFFIN, J. M., FRAISER, M. L., CLAPHAM, M. E., 2012. Paleoecology and geochemistry of Early Triassic (Spathian) microbial mounds and implications for anoxia following the end-Permian mass extinction. Geology, 40, 715-718.

MARKOV, A. V. and KOROTAYEV, A. V. 2007. Phanerozoic marine biodiversity follows a hyperbolic trend. Paleoworld, 16, 311-318.

MARTINDALE, E. C., FOSTER, W. J. and VELLEDITS, F. 2019. The survival, recovery, and diversification of metazoan reefs following the end-Permian mass extinction event. Palaeogeography, Palaeoclimatology, Palaeoecology, 513, 100-115.

MILLER, A. I. and SEPKOSKI, J. 1988. Modeling bivalve diversification: the effect of interaction on a macroevolutionary system. Paleobiology, 14, 364-369.

NAWROCKI, J. and SZULC, J. 2000. The Middle Triassic magnetostratigraphy from the PeriTethys basin in Poland. Earth and Planetary Science Letters, 182, 77-92.

NÜTZEL, A. 2005. Recovery of gastropods in the Early Triassic. C. R. Palevol, 4, 501-515.

NÜTZEL, A. and SCHULBERT, C. 2005. Facies of two important Early Triassic gastropod lagerstätten: Implications for diversity patterns in the aftermath of the end-Permian mass extinction. Facies, 51, 480-500.

NÜTZEL, A., KAIM, A. and GRĂDINARU, E. 2018. Middle Triassic (Anisian, Bithynian) gastropods from North Dobrogea (Romania) and their significance for gastropod recovery from the end-Permian mass extinction event. Papers in Palaeontology, 1-36.

OGILVIE GORDON, M. M. (927. Das Grödener-, Fassa- und Enneberggebiet in den Südtiroler Dolomiten. Geologische Bundesanstalt Wien.

OJI, T. and TWITCHETT, R. J. 2015. The oldest post-Palaeozoic crinoid and Permian-Triassic origins of the articulata (echinodermata). Zoological science, 32, 211-215.

ORCHARD, M. J. 2007. Conodont diversity and evolution through the latest Permian and Early Triassic upheavals. Palaeogeography, Palaeoclimatology, Palaeoecology, 252, 93-117.

PAYNE, J. L. 2005. Evolutionary dynamics of gastropod size across the end-Permian extinction and through the Triassic recovery interval. Paleobiology, 31, 269-290.

PAYNE, J. L., LEHRMANN, D. J., CHRISTENSEN, S., WEI, J. and KNOLL, A. H. 2006 a. Environmental and biological controls on the initiation and growth of a Middle Triassic (Anisian) reef complex on the Great Bank of Guizhou, Guizhou Province, China. Palaios, 21, 325-343.

PAYNE, J. L., LEHRMANN, D. J., FOLLETT, D., SEIBEL, M., KUMP, L. R., RICCARDI, A., 
771

772

773

774

775

776

777

778

779

780

781

782

783

784

785

786

787

788

789

790

791

792

793

794

795

796

797

798

799

800

801

802

803

804

805

ALTINER, D., SANO, H. and WEI, J. 2007. Erosional truncation of uppermost Permian shallow-marine carbonates and implications for Permian-Triassic boundary events. Geological Society of America Bulletin, 119, 771-784.

PAYNE, J. L., LEHRMANN, D. J., WEI, J. and KNOLL, A. H. 2006b. The pattern and timing of biotic recovery from the end-Permian extinction on the Great Bank of Guizhou, Guizhou Province, China. Palaios, 21, 63-85.

PAYNE, J. L., TURCHYN, A. V., PAYTAN, A., DEPAOLO, D. J., LEHRMANN, D. J., YU, M. and WEI, J. 2010. Calcium isotope contraints on the end-Permian mass extinction. Proceedings of the National Academy of Science, 107, 8543-8548.

PETERS, S. E. and FOOTE, M. 2002. Determinants of extinction in the fossil record. Nature, 416, 420-424.

PIROS, O. and PRETO, N. 2008. Dasycladalean algae distribution in ammonoid-bearing Middle Triassic platforms (Dolomites, Italy). Facies, 54, 581-595.

PITACCO, V., ORLANDO-BONACA, M., MAVRIČ, B., POPOVIČ, A. and LIPEJ, L. 2014. Mollusc fauna associated with the Cystoseira algal associations in the Gulf of Trieste (Northern Adriatic Sea). Mediterranean Marine Science, 15.

POPA, L., PANAIOTU, C. E. and GRǍDINARU, E. 2014. An early Middle Anisian (Middle Triassic) Tubiphytes and cement crusts-dominated reef from North Dobrogea (Romania): Facies, depositional environment and diagenesis. Acta Geologica Polonica, 64, 189-206.

POULICEK, M. 1985. Les mollusques des biocénoses à algues photophiles en Méditerranée: II. Analyse du peuplement Cahiers de biologie marine, 26, 127-136.

PRUSS, S. B. and BOTTJER, D. J. 2004. Early Triassic trace fossils of the western United States and their implications for prolonged environmental stress from the end-Permian mass extinction. Palaios, 19, 551-564.

PRUSS, S. B., BOTTJER, D. J., CORSETTI, F. A. and BAUD, A. 2006. A global marine sedimentary response to the end-Permian mass extinction: examples from southern Turkey and the western United States. Earth-Science Reviews, 78, 193-206.

PRUSS, S. B., PAYNE, J. L. and WESTACOTT, S. 2015. Taphonomic bias of selective silicification revealed by paires petrographic and insoluble analysis. Palaios, 30, 620-626.

PRUSS, S. B., PAYNE, J. L., BOTTJER, D. J., 2007. Placunopsis bioherms; the firstmetazoan buildups following the end-Permian mass extinction. Palaios, 22, 17-23.

RAUP, D. M. 1979. Size of the permo-triassic bottleneck and its evolutionary implications. Science, 206, 217-218.

RODEN, V. J., HAUSMANN, I., NÜTZEL, A., SEUSS, B., REICH, M., URLICHS, M., HAGDORN, H. and KIESSLING, W. 2020. Fossil liberation: A model to explain high 
806

807

808

809

810

811

812

813

814

815

816

817

818

819

820

821

822

823

824

825

826

827

828

829

830

831

832

833

834

835

836

837

838

839

840

biodiversity in the Triassic Cassian Formation. Palaeontology, 63, 85-102.

ROMANO, C., GOUDEMAND, N., VENNEMANN, T., WARE, D., SCHNEEBELIHERMANN, E., HOCHULI, P. A., BRÜHWILER, T., BRINKMANN, W. and BUCHER, H. 2013. Climate and biotic upheavals following the end-Permian mass extinction. Nature Geoscience, 6, 57-60.

ROTHMAN, D. H., FOURNIER, G. P., FRECH, K. L., ALM, E. J., BOYLE, E. A., CAO, C., SUMMONS, R.E. 2014. Methanogenic burst in the end-Permian carbon cylce. Proceedings of the National Academy of Sciences, 111, 5462-5467.

RUSSO, F., MASTANDREA, A., STEFANI, M. and NERI, C. 2000. Carbonate facies dominated by syndepositional cements: a key component of Middle Triassic platforms. The Marmolada case history (Dolomites, Italy). Facies, 42, 211-226.

SÁNCHEZ-MOYANO, J. E., ESTACIO, F. J., GARCÍA-ADIEGO, E. M. and GARCIÁGÓMEZ, J. C. 2000. The molluscan epifauna of the alga Halopteris scoparia in southern Spain as a bioindicator of coastal environmental conditions. Journal of Molluscan Studies, 66, 431-448.

SANEI, H., GRASBY, S. E., BEAUCHAMP, B. 2012. Latest Permian mercury anomalies. Geology, 40, 63-66.

SCHEYER, T. M., ROMANO, C., JENKS, J. and BUCHER, H. 2014. Early Triassic Marine Biotic Recovery: The Predators' Perspective. PLoS ONE, 9, e88987, doi:10.1371/journal.pone.00889

SCHMIDT, M. 1928. Die Lebewelt unserer Trias. Hohenlohesche Buchhandlung F. Rau, Öhringen.

SCHMIDT, M. 1938. Die Lebewelt unserer Trias - Nachtrag. Hohenlohesche Buchhandlung F. Rau, Öhringen.

SCHOBBEN, M., JOACHIMSKI, M. M., KORN, D., LEDA, L., KORTE, C. 2014. Palaeotethys seawater temperature rise and an intensified hydrological cycle following the end-Permian mass extinction. Gondwana Research, 26, 675-682.

SCHUBERT, J. K. and BOTTJER, D. J. 1995. Aftermath of the Permian-Triassic mass extinction event: Paleoecology of Lower Triassic carbonates in the western USA. Palaeogeography, Palaeoclimatology, Palaeoecology, 116, 1-39.

SELLWOOD, B. W. and FÜRSICH, F. T. 1981. Die Trias. In Palökologie, Franckh'sche Verlagshandlung, W. Keller \& Co., Stuttgart, 248 pp.

SENOWBARI-DARYAN, B. and LINK, M. 2011. Hypercalcified segmented sponges ('sphinctozoans') from the upper Triassic (Norian) reef boulders of Taurus Mountains (southern Turkey). Facies, 57, 663-693. 
841

842

843

844

845

846

847

848

849

850

851

852

853

854

855

856

857

858

859

860

861

862

863

864

865

866

867

868

869

870

871

872

873

874

875

SENOWBARI-DARYAN, B., ZÜHLKE, R.; BECHSTÄDT, T., and FLÜGEL, E. 1993. Anisian (Middle Triassic) Buildups of the Northern Dolomites (Italy): The Recovery of Reef Communities ater the Permian/Triassic Crisis. Facies, 28, 181-256.

SEPKOSKI, J. J. 1978. A kinetic model of Phanerozoic taxonomic diversity. I. Analysis of marine orders. Paleobiology, 4, 223-251.

SEPKOSKI, J. J. 1984. A kinetic model of Phanerozoic taxonomic diversity. III. Post-Paleozoic families and mass extinctions. Paleobiology, 10, 246-267.

SEPKOSKI, J. J. 1997. Biodiversity: Past, present, and future. Journal of Paleontology, 71, 533539.

SHIGETA, Y., ZAKHAROV, Y. D., MAEDA, H. and POPOV, A. M. 2009. The Lower Triassic System in the Abrek Bay area, South Primorye, Russia. Vol. 38. National Museum of Nature and Science Monographs.

SALOMON, W. 1895. Geologische und palaeontologische Studien über die Marmolata. Palaeontographica, 42, 1-210.

SOLÉ, R. V., SALDAÑA, J., MONTOYA, J. M. and ERWIN, D. H. 2010. Simple model of recovery dynamics after mass extinction. Journal of Theoretical Biology, 267, 193-200.

SONG, H., WIGNALL, P. B., CHEN, Z.-Q., TONG, J., BOND, D. P. G., LAI, X., ZHAO, X., JIANG, H., YAN, C., NIU, Z., CHEN, J., YANG, H. and WANG, Y. 2011. Recovery tempo and pattern of marine ecosystems after the end-Permian mass extinction. Geology, 39, 739-742.

SONG, H., WIGNALL, P.B., CHU, D., TONG, J., SUN, Y., SONG, H., HE, W., \& TIAN, L. 2014. Anoxia/high temperature double whammy during the Permian-Triassic marine crisis and its aftermath. Scientific reports, 4, 4132.

STANLEY, S. M. 2016. Estimates of the magnitudes of major marine mass extinctions in earth history. Proceedings of the National Academy of Sciences, 113, E6325-E6334.

STILLER, F. 2001. Fossilvergesellschaftungen, Paläökologie und paläosynökologische Entwicklung im Oberen Anis (Mittlere Trias) von Qingyan, insbesondere Bangtoupo, Provinz Guizhou, Südwestchina. Münstersche Forschung zur Geologie und Paläontologie, 92, 1-523.

SUN, J., JOACHIMSKI, M. M., WIGNALL, P. B., YAN, C., CHEN, Y., JIANG, H., WANG, L. and LAI, X. 2012. Lethally Hot Temperatures During the Early Triassic Greenhouse. Science, 338, 366-370.

TAYLOR, J. D. 1971. Reef associated molluscan assemblages in the Western Indian Ocean. In STODDART, D. R. and YONGE, M. (eds.) Regional Variation in Indian Ocean Coral Reefs, Symposia of the Zoological Society of London, 501-534 pp. 
876

877

878

879

880

881

882

883

884

885

886

887

888

889

890

891

892

893

894

895

896

897

898

899

900

901

902

903

904

905

906

907

908

909

910

911

THOMASSIN, B. A. 1971. Les faciès d'épifauna et d'épiflore des biotopes sédimentaires des formations coralliennes dans la région de Tuléar (sud-ouest de Madagascar). In STODDARD, D. R. and YONGE, M. (eds.) Regional Variation in Indian Ocean Coral Reefs, London, 501-534 pp.

TIAN, L., TONG, J., ALGEO, T. J., SONG, H., SONG, H., CHU, D., SHI, L. and BOTTJER, D. J. 2014. Reconstruction of Early Triassic ocean redox conditions based on framboidal pyrite from the Nanpanjiang Basin, South China. Palaeogeography, Palaeoclimatology, Palaeoecology, 412, 68-79.

TWITCHETT, R. J. and WIGNALL, P. B. 1996. Trace fossils and the aftermath of the PermoTriassic mass extinction: Evidence from northern Italy. Palaeogeography, Palaeoclimatology, Palaeoecology, 124, 137-151.

TWITCHETT, R. J., KRYSTYN, L., BAUD, A., WHEELEY, J. R. and RICHOZ, S. 2004. Rapid marine recovery after the end-Permian mass-extinction event in the absence of marine anoxia. Geology, 32, 805-808.

UNDERWOOD, A. J. 1980. The effects of grazing by gastropods and physical factors on the upper limis of distribution of intertidal macroalgae. Oecologia, 46, 201-213.

URLICHS, M. 2014. A phylogenetic lineage of Myophoria kefersteini subspecies (Bivalvia) from the Late Ladinian to the Early Carnian (Triassic) in the Dolomites and Julian Alps (Italy). Neues Jahrbuch für Geologie und Paläontologie, Abhandlungen, 274, 187-207.

URLICHS, M. 2017. Revision of some stratigraphically relevant ammonoids from the Cassian Formation (latest Ladinian-Early Carnian, Triassic) of St. Cassian (Dolomites, Italy). Neues Jahrbuch für Geologie und Paläontologie, Abhandlungen, 283, 173-204.

VALENTINE, J. W. 1971. Resource supply and species diversity patterns. Lethaia, 4, 51-61.

VELLEDITS, F., HIPS, K. and PÉRÓ, C. 2012. Lower and Middle Triassic succession in Aggtelek Karst. IGCP 572 field trip POST 2. June 5-7, 1-33.

VELLEDITS, F., PÉRÓ, C., BLAU, J., SENOWBARI-DARYAN, B., KOVÁCS, S., PIROS, O., POCSAI, T., SZÜIGYI-SIMON, H., DUMITRICǍ, P. and PÁLFY, J. 2011. The oldest Triassic platform margin reef from the Alpine - Carpathian region (Aggtelek, NE Hungary): Platform evolution, reefal biota and biostratigraphic framework. Rivista Italiana di Paleontologia e Stratigrafia, 117, 221-268.

VERON, J. E., DEVANTIER, L. M., TURAK, E., GREEN, A. L., KININMONTH, S., STAFFORD-SMITH, M. and PETERSON, N. 2009. Delineating the coral triangle. Galaxea, Journal of Coral Reef Studies, 11, 91-100.

WASMER, M., HAUTMANN, M., HERMANN, E., WARE, D., ROOHI, G., UR-REHMAN, K., YASEEN, A. and BUCHER, H. 2012. Olenekian (Early Triassic) bivalves from the Salt Range and Surghar Range, Pakistan. Palaeontology, 55, 1043-1073.

Peer] reviewing PDF | (2020:10:54335:1:0:NEW 7 May 2021) 
912 WEI, H., SHEN, J., SCHOEPFER, S.D., KRYSTYN, L., RICHOZ, S., \& ALGEO, T.J. 2015.

913 Environmental controls on marine ecosystem recovery following mass extinctions, with an

914 example from the Early Triassic. Earth-Science Reviews, 149, 108-135.

915 WHEELEY, J. R. and TWITCHETT, R. J. 2005. Palaeoecological significance of a nes

916 Griesbachian (Early Triassic) gastropod assemblage from Oman. Lethaia, 38, 37-45.

917 WIGNALL, P. B. and BENTON, M. J. 1999. Lazarus taxa and fossil abundances at times of

918 biotic crises. Journal of the Geological Society, 156, 453-456.

919 WIGNALL, P. B. and TWITCHETT, R. J.,1996. Oceanic anoxia and the end-Permian mass 920 extinction. Science 272, 1155-1158.

921 WILLIAMS, G. A. 1993. Seasonal variation in algal species richness and abundance in the

922

923

924 WU, Y., JIANG, H., YANG, W. and FAN, J., 2007. Microbialite of anoxic condition from

925

926 presence of molluscan herbivores on a tropical rock shore. Journal of Experimental Marine Biology and Ecology, 167, 261-275.

927

928

929

YANG, H., CHEN, Z.-Q., WANG, Y., OU, W., LIAO, W. and MEI , X., 2015. Palaeoecology of microconchids from microbialites near the Permian-Triassic boundary in South China. Lethaia, 48, 497-508. 


\section{Figure 1}

Maximum species richness throughout the Early and Middle Triassic.

The Longobardian is palish to indicate that the decrease of species richness is not a primary signal. Light grey bars on top indicate the number of lithological units representing each time interval. In cases where information does not come from all lithological units representing the corresponding time interval, the actual number of lithological units from which information comes from is indicated by dark grey bars. Abbreviations: $A=$ Aegean, $B=$ Bithynian, $D=$ Dienerian, Fassan = Fassanian, $\mathrm{G}=$ Griesbachian, I = Induan, Illyr = Illyrian, Longobard = Longobardian, Pelson = Pelsonian, $\mathrm{Sm}=$ Smithian. Absolute ages according to (Cohen et al., 2013, updated). Information about the relative duration of substages come from Nawrocki \& Szulc (2000), Götz, Szulc \& Feist-Burkhardt (2005), Jattiot et al. (2018) and Li et al. (2018). Symbols for ecological guilds redrawn after Aberhan (1994). See text for further explanation. 

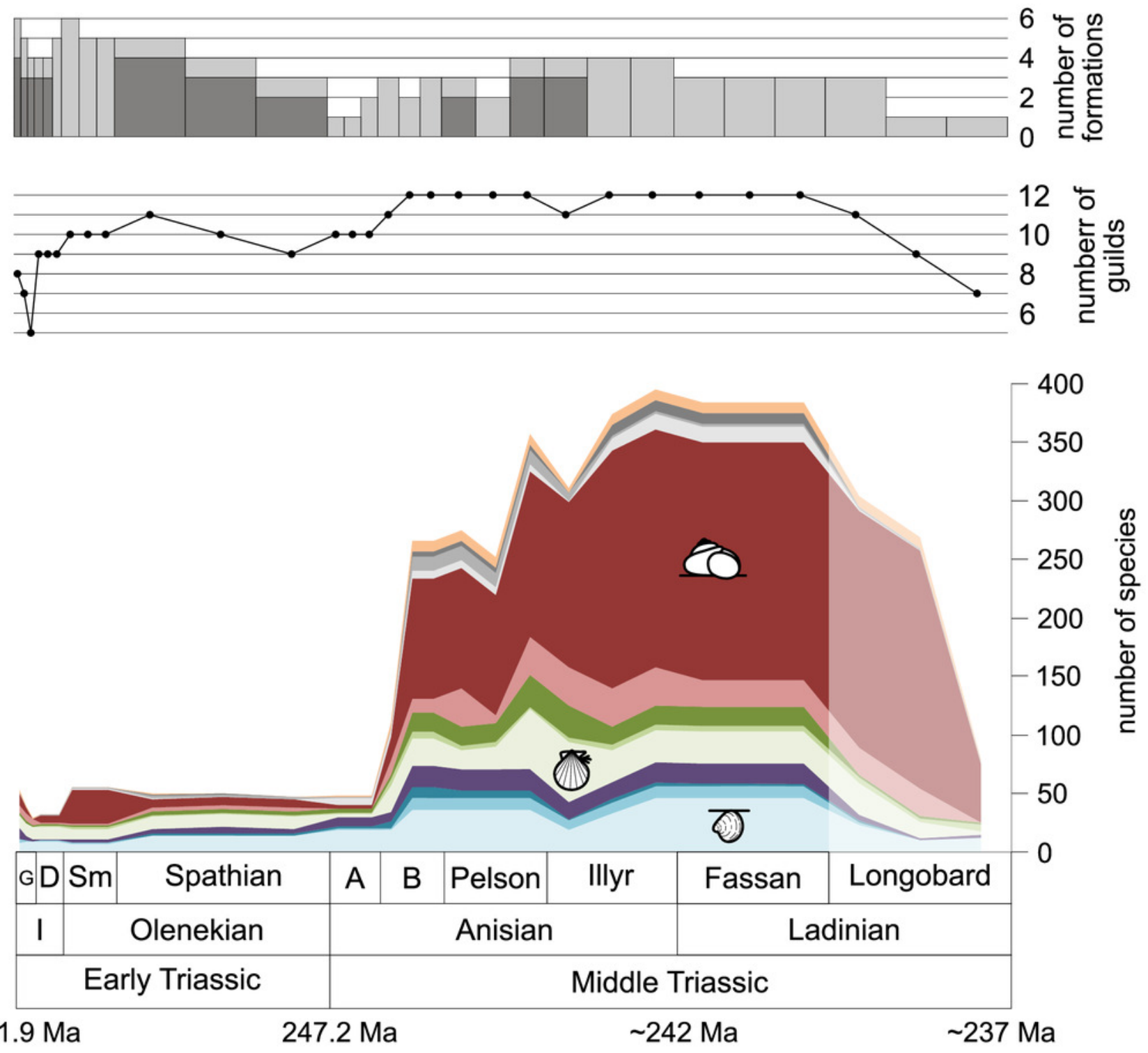

\section{$251.9 \mathrm{Ma}$}

247.2 Ma

free-lying

suspension-feeders

infaunal suspension-feeders

shallow infaunal

deposit-feeders

deep infaunal

suspension-feeders

endobyssate

suspension-feeders

epibyssate

suspension-feeders cemented epifaunal suspension-feeders

pedunculate

suspension-feeders

epifaunal herbivores

and/or detritus-feeders

epifaunal carnivores erected epifaunal suspension-feeders epifaunal detrivoresuspension-feeders uncertain ecology 


\section{Figure 2}

Maximum species richness in different environments.

(A) lagoons, (B) inner ramps, (C) mid-ramps and (D) outer ramps. The Longobardian is palish to indicate that the decrease of species richness is not a primary signal. Light grey bars on top indicate the number of lithological units representing each time interval. In cases where information does not come from all lithological units representing the corresponding time interval, the actual number of lithological units from which information comes from is indicated by dark grey bars. Due to our data selection, the following guilds are not shown in this figure although reported in polished slabs: shallow infaunal deposit-feeders in late Griesbachian-Smithian and middle Spathian inner ramps (one species, respectively) and Smithian mid-ramps (one species), cemented epifaunal suspension-feeders in early-middle Spathian inner ramps (one species) and Dienerian-Smithian outer ramps (two species), epifaunal herbivores and/or detritus-feeders in early-middle Spathian (two species) and late Pelsonian-early Illyrian (five species) outer ramps. Abbreviations, symbols for ecological guilds and information about the relative duration of substages as in Figure 1. See text for further explanation. 
A
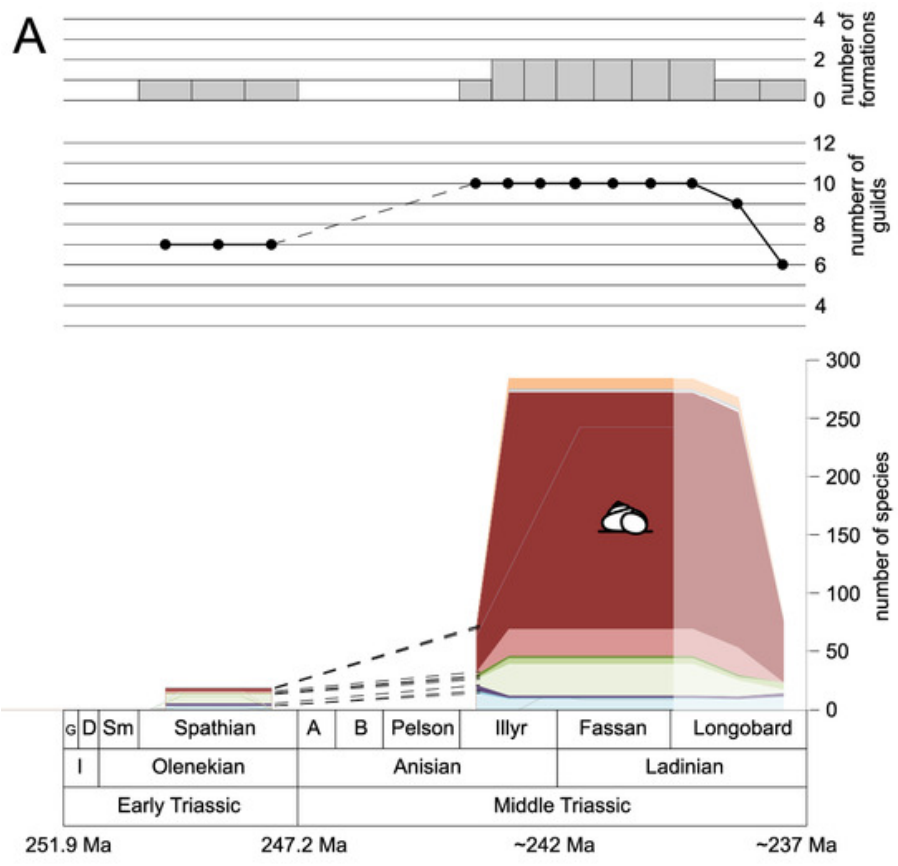

C
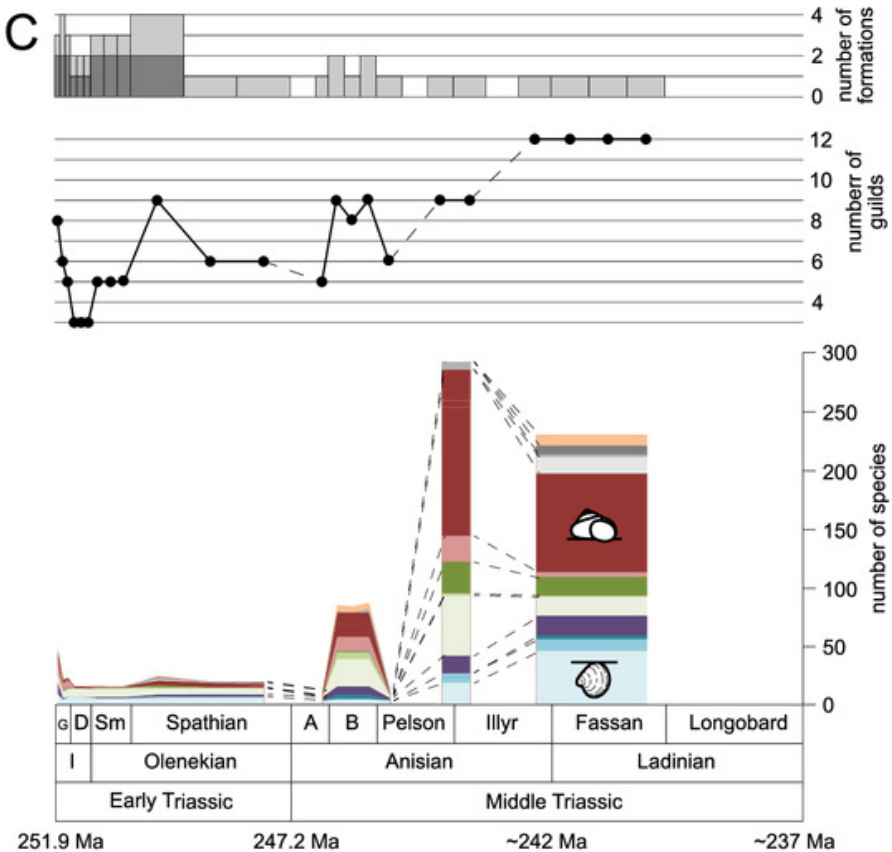

$251.9 \mathrm{Ma}$ $247.2 \mathrm{Ma}$

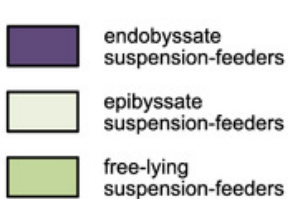

B
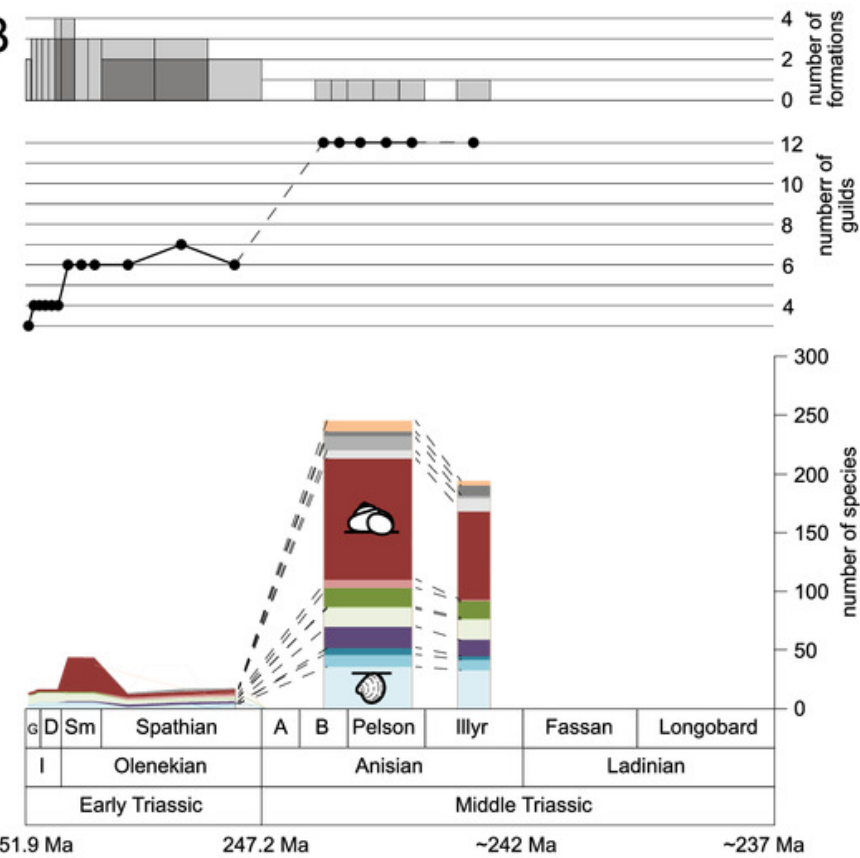

D
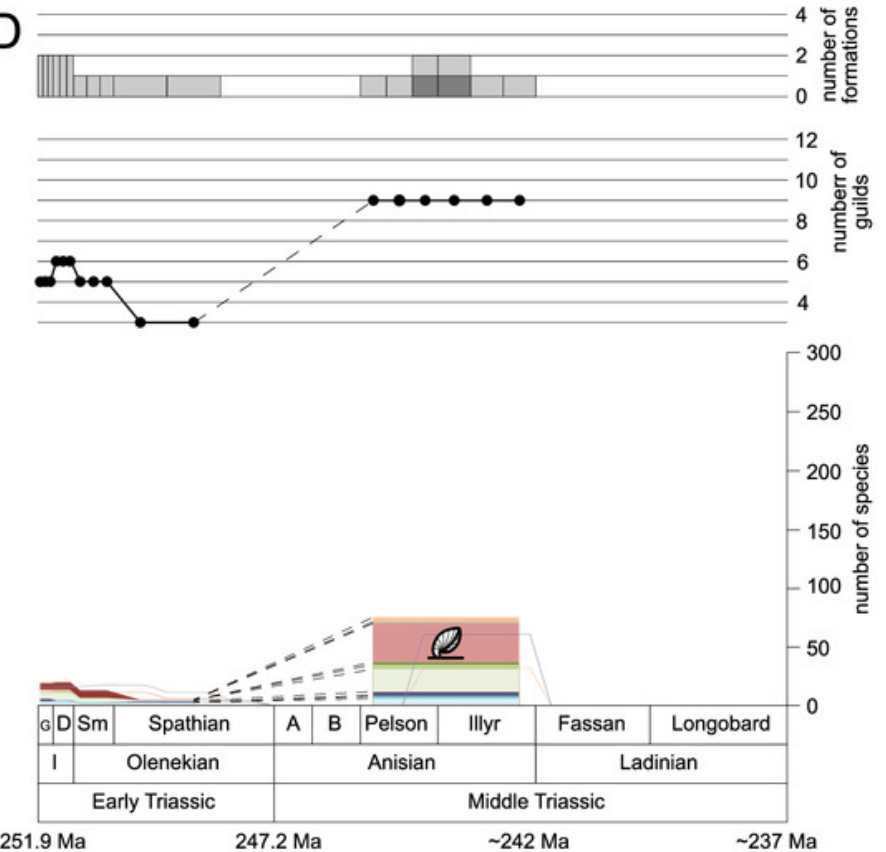

$251.9 \mathrm{Ma}$ $\sim 242 \mathrm{Ma}$

$\sim 237 \mathrm{Ma}$ cemented epifaunal suspension-feeders

pedunculate

suspension-feeders

shallow infauna deposit-feeders

deep infaunal

suspension-feeders epifaunal carnivores

erected epifaunal suspension-feeders

epifaunal detrivoresuspension-feeders 


\section{Figure 3}

Guild-species diversity throughout the Early and Middle Triassic.

Bars on top indicate the number of lithological units representing each time interval.

Abbreviations, symbols for ecological guilds and information about the relative duration of substages as in Figure 1. See text for further explanation.
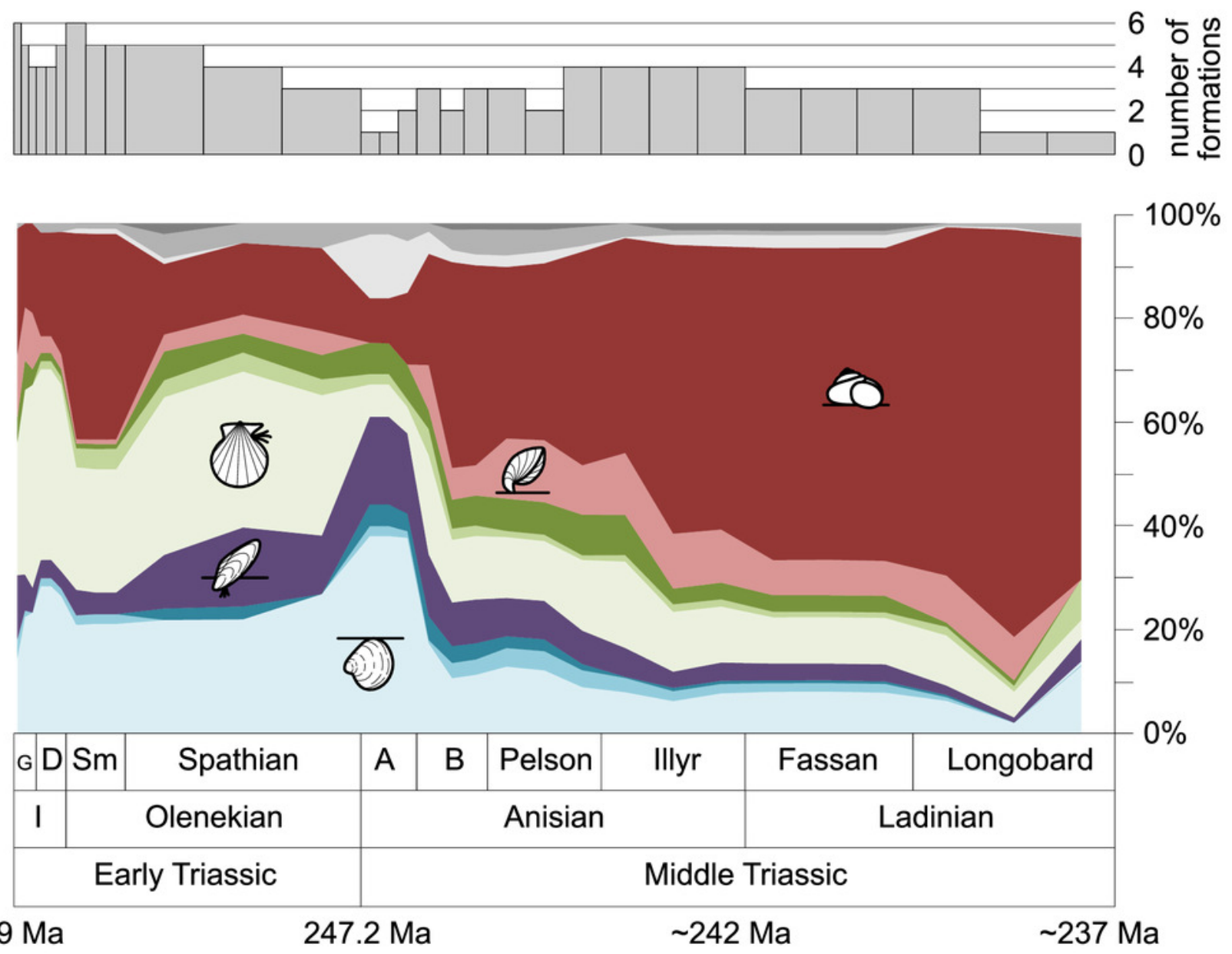

shallow to moderately deep infaunal suspension-feeders shallow infaunal deposit-feeders deep infaunal suspension-feeders endobyssate suspension-feeders

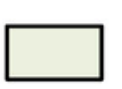

epibyssate suspension-feeders free-lying suspension-feeders cemented epifaunal suspension-feeders pedunculate suspension-feeders epifaunal herbivores and/or detritus-feeders

epifaunal carnivores erected epifaunal suspension-feeders epifaunal detrivoresuspension-feeders 


\section{Figure 4}

Guild-species diversity of different environments.

(A) lagoons, (B) inner ramps, (C) mid-ramps and (D) outer ramps. Bars on top indicate the number of lithological units representing each time interval. Due to our data selection, the following guilds are not shown in this figure although reported in polished slabs: shallow infaunal deposit-feeders in late Griesbachian-Smithian and middle Spathian inner ramps (one species, respectively) and Smithian mid-ramps (one species), cemented epifaunal suspension-feeders in early-middle Spathian inner ramps (one species) and DienerianSmithian outer ramps (two species), epifaunal herbivores and/or detritus-feeders in earlymiddle Spathian (two species) and late Pelsonian-early Illyrian (five species) outer ramps. Abbreviations, symbols for ecological guilds and information about the relative duration of substages as in Figure 1. See text for further explanation. 

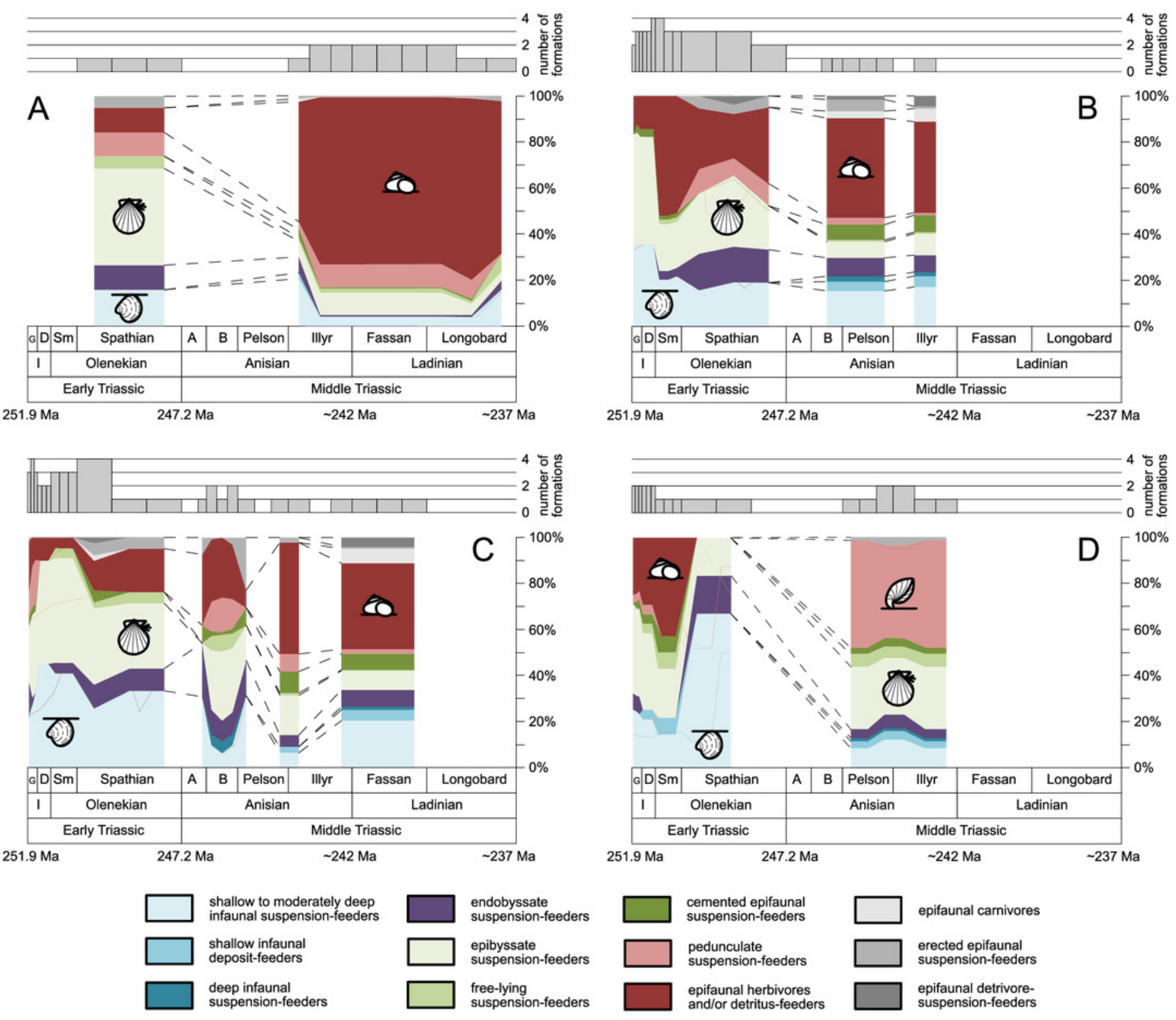


\section{Figure 5}

Maximum species richness throughout the Early and Middle Triassic of ecological guilds.

(A-B) epifaunal herbivores and/or detritus-feeders, (C-D) shallow to moderately deep infaunal suspension-feeders, endobyssate suspension-feeders, epibyssate suspension-feeders and pedunculate suspension-feeders, (E-F) shallow infaunal deposit-feeders, deep infaunal suspension-feeders, free-lying suspension-feeders and cemented microcarnivores, (G-H) cemented epifaunal suspension-feeders, erected epifaunal suspension-feeders, epifaunal carnivores and epifaunal-detrivore-suspension-feeders. Number of species illustrated with linear scale (A, C, E and $G)$ and logarithmic scale (B, D, F and H). Filled symbols represent faunas that are more or as diverse as older ones, whereas empty symbols represent faunas that are less diverse than older ones. Abbreviations and information about the relative duration of substages as in Figure 1. See text for further explanation. 


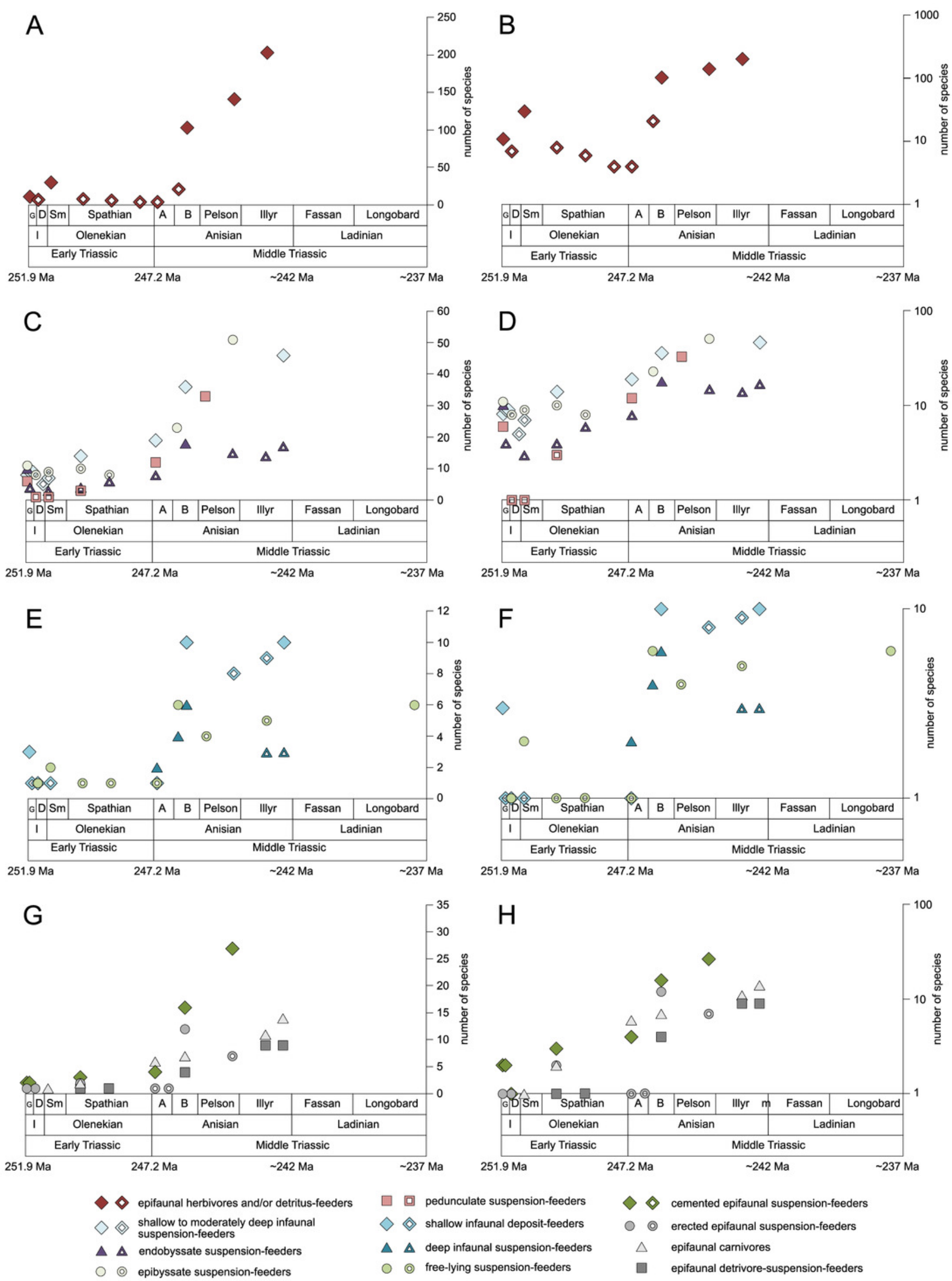

Peer) reviewing PDF | (2020:10:54335:1:0:NEW 7 May 2021) 
Figure 6

Species richness of the most diverse taxa and the gastropod/bivalve-ratio throughout the Early and Middle Triassic.

(A) bivalves, (B) gastropods, (C) brachiopods and (D) the gastropod/bivalve-ratio. Each line represents one lithological unit. Red lines mark lithological units and ratios associated with carbonate platforms. Abbreviations and information about the relative duration of substages as in Figure 1. (A) modified after Friesenbichler et al. (2021) and (D) modified after Friesenbichler et al. (2019b). See text for further explanation.
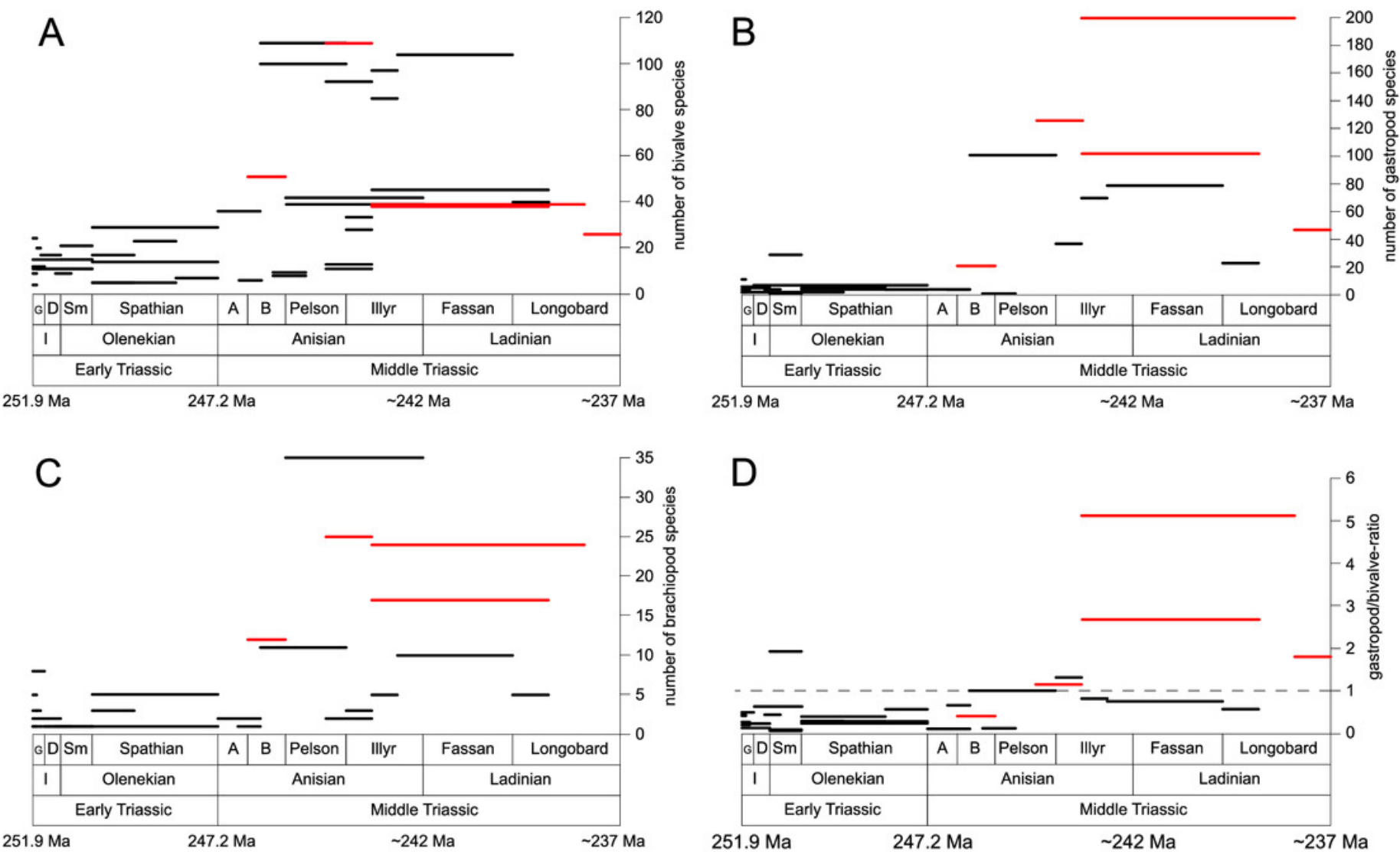
Figure 7

Maximum species richness throughout the Early and Middle Triassic of bivalves, gastropods and brachiopods.

$(A-B)$ in general and $(C-D)$ in mid-ramps. Number of species illustrated with linear scale $(A$ and $C$ ) and logarithmic scale (B and D). Filled symbols represent faunas that are more or as diverse as older ones, whereas empty symbols represent faunas that are less diverse than older ones. Abbreviations and information about the relative duration of substages as in Figure 1. See text for further explanation.

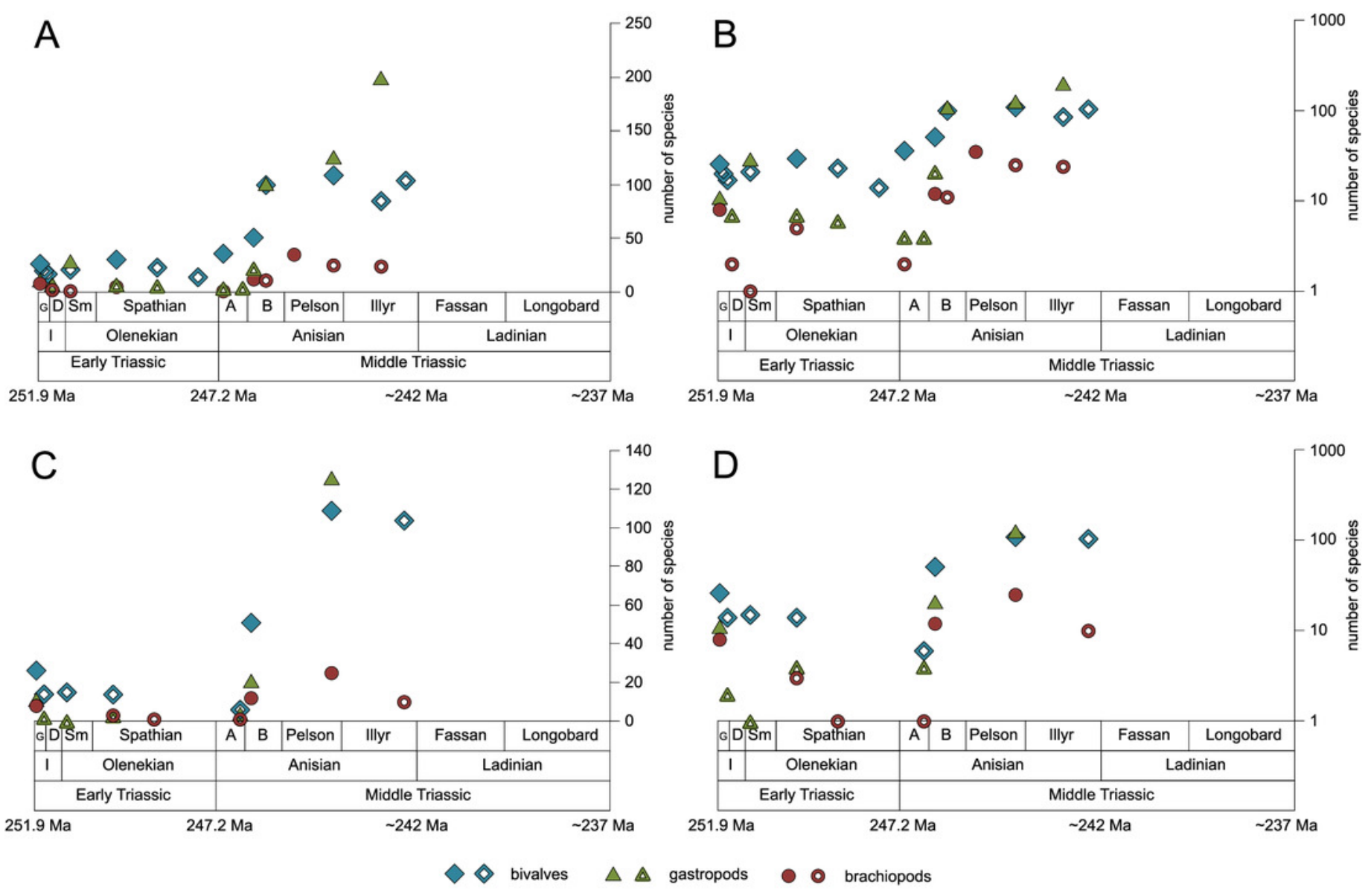


Figure 8

Diversification curves.

(A-B) Logistic with number of species illustrated with linear scale (A) and logarithmic scale (B). (C-D) Hyperbolic-damped with number of species illustrated with linear scale (C) and logarithmic scale (D).

A

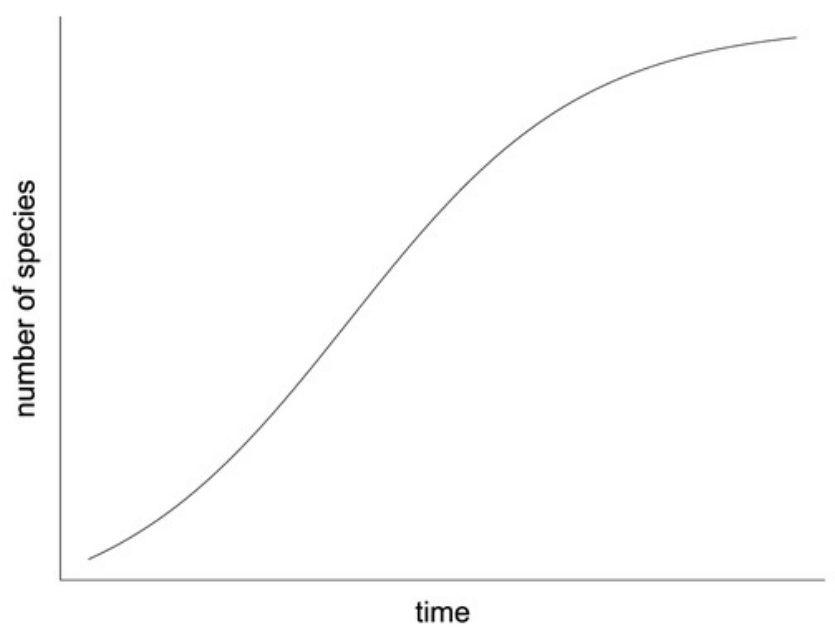

C

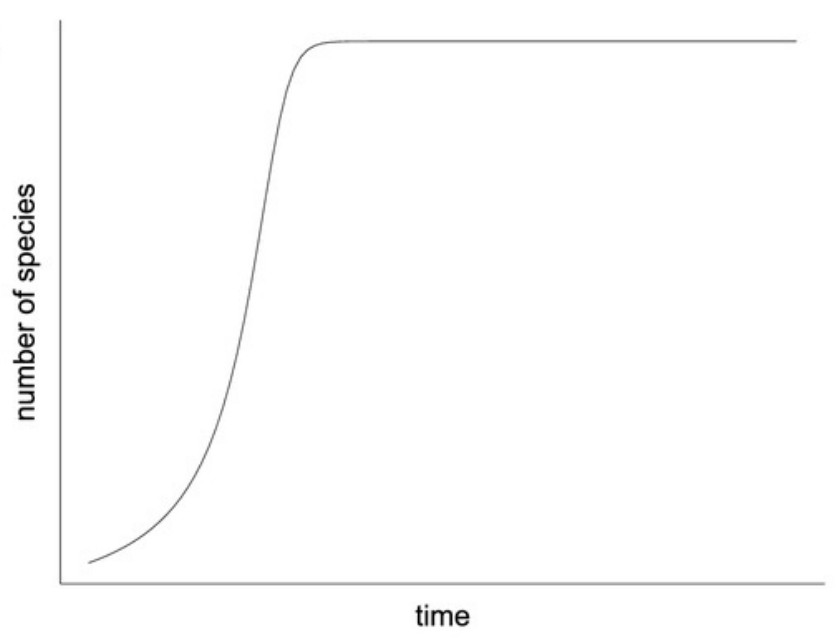

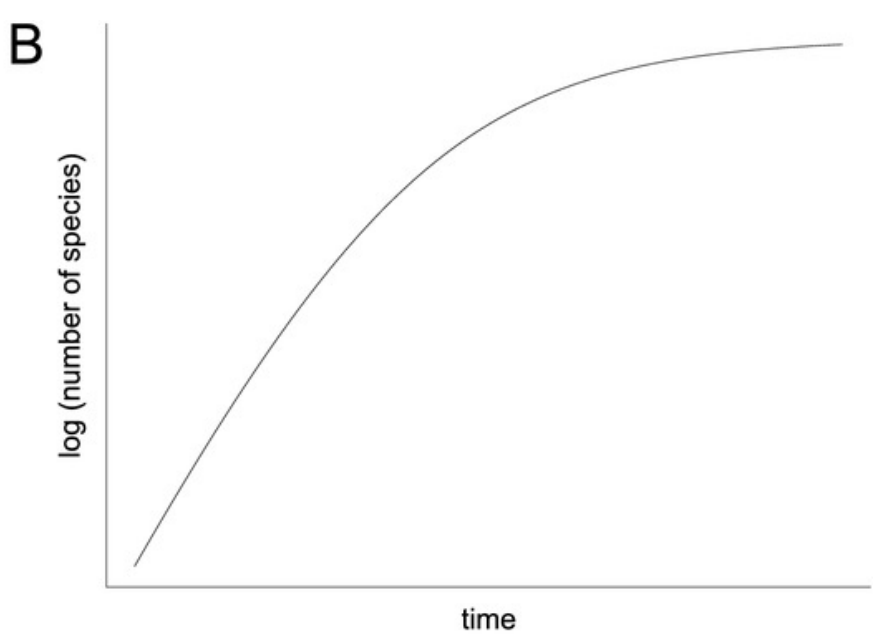

D

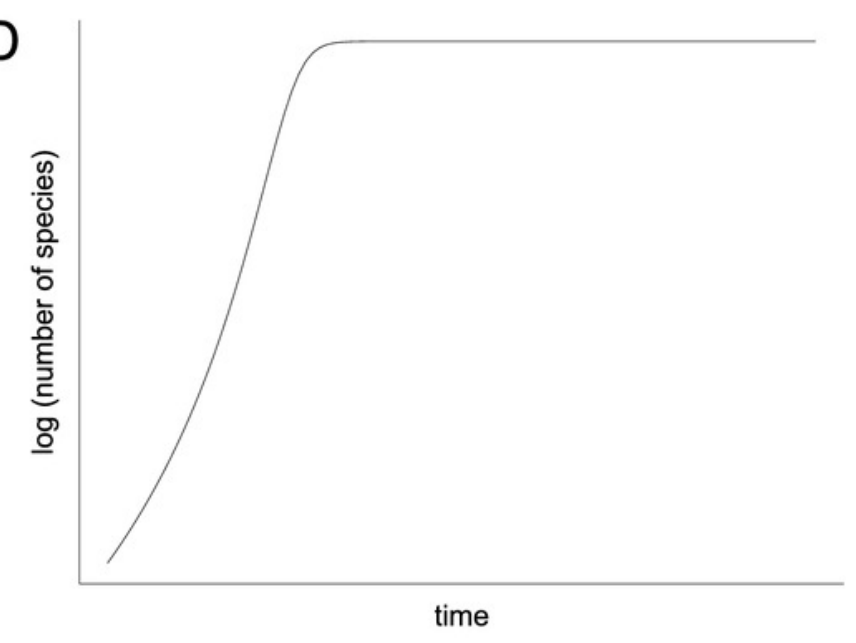


Table $\mathbf{1}$ (on next page)

List of ecological guilds and representing taxa. 


\begin{tabular}{|l|l|}
\hline Ecological guild & Taxa \\
\hline $\begin{array}{l}\text { Shallow to moderately deep infaunal } \\
\text { suspension-feeders }\end{array}$ & Bivalves, inarticulate brachiopods \\
\hline Shallow infaunal deposit-feeders & Bivalves, scaphopods \\
\hline Deep infaunal suspension-feeders & Bivalves \\
\hline Endobyssate suspension-feeders & Bivalves \\
\hline Epibyssate suspension-feeders & Bivalves \\
\hline Free-lying epifaunal suspension-feeders & Bivalves \\
\hline Cemented epifaunal suspension-feeders & Bivalves, serpulids, inarticulate brachiopods, \\
\hline bryozoans, microconchids \\
\hline Pedunculate suspension-feeders & Articulate brachiopods \\
\hline Epifaunal herbivores and/or detritus-feeders & Gastropods, echinoids, polyplacophors \\
\hline Epifaunal carnivores & Asteroids, crustaceans \\
\hline
\end{tabular}

